IZA DP No. 4455

What Should Be Done About Rising Unemployment in the OECD?

David N.F. Bell

David G. Blanchflower

September 2009 


\title{
What Should Be Done About Rising Unemployment in the OECD?
}

\author{
David N.F. Bell \\ University of Stirling \\ and IZA
}

David G. Blanchflower

Dartmouth College, University of Stirling,

NBER, CESifo and IZA

\section{Discussion Paper No. 4455 \\ September 2009}

\author{
IZA \\ P.O. Box 7240 \\ 53072 Bonn \\ Germany \\ Phone: +49-228-3894-0 \\ Fax: +49-228-3894-180 \\ E-mail: iza@iza.org
}

\begin{abstract}
Any opinions expressed here are those of the author(s) and not those of IZA. Research published in this series may include views on policy, but the institute itself takes no institutional policy positions.

The Institute for the Study of Labor (IZA) in Bonn is a local and virtual international research center and a place of communication between science, politics and business. IZA is an independent nonprofit organization supported by Deutsche Post Foundation. The center is associated with the University of Bonn and offers a stimulating research environment through its international network, workshops and conferences, data service, project support, research visits and doctoral program. IZA engages in (i) original and internationally competitive research in all fields of labor economics, (ii) development of policy concepts, and (iii) dissemination of research results and concepts to the interested public.
\end{abstract}

IZA Discussion Papers often represent preliminary work and are circulated to encourage discussion. Citation of such a paper should account for its provisional character. A revised version may be available directly from the author. 
IZA Discussion Paper No. 4455

September 2009

\section{ABSTRACT}

\section{What Should Be Done About Rising Unemployment in the OECD?}

There is a growing belief that the recession has run its course and that the goods market has started a period of slow, but sustainable, recovery. Improvement in the labor market may take some time, but many believe that unemployment will return to its 2007 level in the medium term. In this paper, we argue that recovery is by no means guaranteed and that the consequences for unemployment may be worse than anticipated.

JEL Classification: J64

Keywords: unemployment, youth

Corresponding author:

David G. Blanchflower

Department of Economics

6106 Rockefeller Hall

Dartmouth College

Hanover, NH 03755-3514

USA

E-mail: blanchflower@dartmouth.edu 


\section{Introduction}

There is a growing belief that the recession has run its course and that the goods market has started a period of slow, but sustainable, recovery. Improvement in the labor market may take some time, but many believe that unemployment will return to its 2007 level in the medium term. In this paper, we argue that recovery is by no means guaranteed and that the consequences for unemployment may be worse than anticipated. Further, the human costs of the increase in unemployment are being consistently understated. As Stiglitz (2008) puts it, the collective failure of governments to adequately control aggregate demand will principally be "the human toll -- families whose life dreams are destroyed as they lose their homes, their jobs, and their life savings." 1

The November 2008 IMF forecast suggested that the global unemployment rate would rise from 5.7 per cent in 2007 to 6.1 per cent in 2009, increasing worldwide unemployment by 18 million. If instead the unemployment rate instead rises to 6.5 per cent during 2009, unemployment will increase by 30 million and in the IMF's worst case scenario, the world unemployment rate could rise to 7.1 per cent, increasing the global number of unemployed by more than 50 million people.

The costs of unemployment will not be shared evenly. They will vary across countries and between groups within populations. We start the paper by considering the world economic outlook, arguing that it is much more fragile than many commentators believe and that return to previous levels of unemployment is not guaranteed. We then examine the increases in unemployment that have already taken place at a country level, looking at how they relate to other economic indicators of the recession. Next we consider the human and social costs of increased unemployment, especially among the young, while the next to last section discusses some policy issues. In the final section we draw some conclusions.

\section{Outlook for the World Economy}

At the beginning of 2009, the OECD economies experienced the most severe downturn in output since the Great Depression. Though the main contributory cause of the downturn lay in US credit markets, European economies which had similarly liberal credit environments or which were reliant on external demand experienced a substantial fall in demand from early 2008. By 2009 every member country of the OECD has experienced increasing unemployment rates.

The securitization of US sub-prime mortgages had a contagious effect on world credit markets. Many large financial institutions withdrew to their home markets and sought to increase their reserves by holding back on lending. It is clear that the price of risk had been too low and was going to have to be re-priced upwards. Almost overnight, credit became very scarce. The financial crisis had a dramatic effect on demand, causing output to decline steeply. Reinhardt and Rogoff (2009) show that financial crises have "deep and lasting

\footnotetext{
${ }^{1}$ Stiglitz, J. (2008) "Global Crisis - Made in America" in Spiegel Online International, December $11^{\text {th }}$, Accessed at: http://www.spiegel.de/international/business/0,1518,590028,00.html
} 
effects on asset prices, output and employment". ${ }^{2}$ More often than not, they argue, the aftermath of severe financial crises share three characteristics. First, asset market collapses are deep and prolonged. Real housing price declines average 35 percent stretched out over six years, while equity price collapses average 55 percent over a downturn of about three and a half years. Second, the aftermath of banking crises is associated with large declines in output and employment. The unemployment rate increases, an average of 7 percentage points over the down phase of the cycle, which lasts, on average over four years. Output falls (from peak to trough) an average of over 9 percent, although the duration of the downturn, averaging roughly two years, is considerably shorter than for unemployment. Third, the real value of government debt tends to explode, rising an average of 86 percent in the major postWorld War II episodes. The government budget constraint implies that any short-run fiscal expansions must be compensated by future reductions in demand and consequent weakened growth.

But the conventional wisdom among macroeconomists was that such a severe recession could not occur. Their attention had shifted from demand-side to supply-side causes of macroeconomic instability. Thus, as Blanchard (2005) notes, explanations of unemployment changed from the effects of shocks in the 1970s, to persistence mechanisms in the 1980s, and finally to labor market institutions such as employment protection and unemployment insurance in the 1990s. ${ }^{3}$ So in most OECD countries, recent policies have focused almost exclusively on removing imperfections from the supply side of the economy, particularly the labor market. Yet the current recession is driven by a collapse of demand - the result of a combination of significant imbalances in demand structures and unsustainable increases in credit. The recent dramatic rise in joblessness has little to do with supply-side explanations of unemployment such as the prevalence of trade unions, wage flexibility, the generosity of unemployment benefits or job protection (See Blanchflower, 2001). ${ }^{4}$

There has been a reduction in the rate of decline of output in the last quarter in most countries. Indeed, in France and Germany, output has started to grow. However, Table 1 shows that out of the thirty-one countries for which data are available on seasonally adjusted volumes of GDP, for all but eight the most recent data show a decline. The exceptions are France (0.3), Germany (0.3\%), Greece (0.3), Poland (0.5), Portugal (0.3), Slovenia (0.7\%), Slovakia (2.2) following a quarterly loss of $-11 \%$ and Sweden $(0 \%)$. More recent data also suggest that recovery may have started in Japan. This does not mean that growth may not turn negative again - a W-shaped recovery - as the demand-depressing effects of increased unemployment start to exert a further negative effect on production and sales. The

\footnotetext{
${ }^{2}$ C.M. Reinhart and K.S. Rogoff (2009), 'The aftermath of financial crises', NBER Working Paper \#14656.

${ }^{3}$ Blanchard, O. (2005) 'European Unemployment: The Evolution of Facts and Ideas', National Bureau of Economic Research, Working Paper 11750

${ }^{4}$ Blanchflower, D.G. (2001), "Unemployment, Well-Being and Wage Curves in Eastern and Central Europe", Journal of Japanese and International Economies, Volume 15, Issue 4, December, pp. 364-402.
} 
interaction between rising unemployment, falling house prices and negative equity are likely to cause further difficulties in those countries where a major cause of the recession has been the collapse of credit markets. Further, it does not mean that the negative effects of this recession on the labor market will be over any time soon. Even if the growth rate turns positive it will be some time before the level of output is restored to pre-recession levels.

As the OECD noted in its interim assessment of the economic outlook for OECD countries on September $3^{\text {rd }} 2009$, there is some evidence of improvement. ${ }^{5}$ Corporate bond spreads have come down. Fewer banks are tightening credit. Share prices have rebounded. Money market stress has eased. Financial conditions have improved. Export orders have firmed. US housing construction may be nearing a bottom. Business confidence has recovered. Estimates for third quarter 2009 GDP have been revised up. However, CDS spreads for banks remain elevated. Consumer confidence remains at very low levels and unemployment continues to rise and employment to fall.

The recent evidence from the Baltic Dry index is also of particular concern (Figure 1). The Baltic Dry Index is a daily average of prices to ship raw materials. It represents the cost paid by an end customer to have a shipping company transport raw materials across seas on the Baltic Exchange, the global marketplace for brokering shipping contracts. The index is quoted every working day at 1300 London time. The Baltic is owned and operated by the member buyers and sellers. The BDI measures the demand to move raw materials and precursors to production, as well as the supply of ships available to move this cargo. "The BDI offers a real time glimpse at global raw material and infrastructure demand. Unlike stock and commodities markets, the Baltic Dry Index is totally devoid of speculative players. The trading is limited only to the member companies, and the only relevant parties securing contracts are those who have actual cargo to move and those who have the ships to move it". ${ }^{6}$

The index moved from approximately its long run average of around 1700 to 11700 in early May 2008 before collapsing to 1463 in early September 2008. It recovered to 4291 in June 2009. Since then it has lost $45 \%$ of its value. On September $4^{\text {th }} 2009$ it stood at 2414. World demand looks to be falling back again.

It remains uncertain to this point whether the recovery, when it comes will be V-shaped or $\mathrm{W}$-shaped or some other letter. The concern is that banks are not lending and much of the positive evidence we have seen is driven by government fiscal and monetary interventions. Countries such as the USA have injected huge fiscal stimuli. The European economies have largely followed suit, including France and Germany. There have been 'cash for clunkers programs, temporary cuts in VAT and subsidies to labour costs that look to have been successful. Monetary policy has also been extremely loose. Interest rates in the Euro area and in the UK and the US are close to the zero bound and even negative in the case of Sweden. Attempts to increase the money supply through quantitative easing continue apace.

\footnotetext{
${ }^{5}$ http://www.oecd.org/dataoecd/10/32/43615812.pdf

${ }^{6}$ http://www.wikinvest.com/index/Baltic_Dry_Index _ BDI_\%28BALDRY\%29
} 
The worry is that once this public stimulus is withdrawn, the private sector is in no position to respond and the various economies will decline once again. This is what Keynes in 1930 called the 'semi-slump'. 7

'The duration of the slump may be much more prolonged than most people are expecting and ... much will be changed both in our ideas and in our methods before we emerge. Not, of course the duration of the acute phase of the slump, but that of the long, dragging conditions of semi-slump, or at least sub-normal prosperity, which may be expected to succeed the acute phase."

Nouriel Roubini, writing in the Financial Times on August $23^{\text {rd }} 2009$ argued the risk of a 'double dip' recession is rising. Roubini called the recession earlier than most. There are several arguments he gives for a weak recovery which we need to take seriously. First, employment is still falling sharply in the US. Second, this is a crisis of solvency, not just liquidity, but true de-leveraging has not begun yet because the losses of financial institutions have been socialized and put on government balance sheets. This, he argues, limits the ability of banks to lend, households to spend and companies to invest. Third, in countries running current account deficits, consumers need to cut spending and save much more, yet debtburdened consumers face a wealth shock from falling home prices and stock markets and shrinking incomes and employment. Fourth, the financial system - despite the policy support - is still severely damaged. Most of the shadow banking system has disappeared, and traditional banks are saddled with trillions of dollars in expected losses on loans and securities while still being seriously under-capitalized. The globalization of the capital market has been abruptly halted, with many banks retreating from foreign markets. Fifth, weak profitability - owing to high debts and default risks, low growth and persistent deflationary pressures on corporate margins - will constrain companies' willingness to produce, hire workers and invest. Sixth, the re-leveraging of the public sector through its build-up of large fiscal deficits risks crowding out a recovery in private sector spending. Moreover, Roubini argues that the effects of the policy stimulus "will fizzle out by early next year", requiring greater private demand to support continued growth. Seventh, the reduction of global imbalances implies that the current account deficits of profligate economies, such as the US, will narrow the surpluses of countries that over-save (China and other emerging markets, Germany and Japan).

The recovery is certainly not over and is threatened by countries removing the various stimuli too quickly. This was exactly the point made by Dominique Strauss-Kahn, Managing Director of the International Monetary Fund, at the Sixth Annual Bundesbank Lecture in Berlin on September 4, 2009. ${ }^{8}$

\footnotetext{
7 'An economic analysis of unemployment' by J.M. Keynes in 'Unemployment as a world-problem' By Quincy Wright, John Maynard Keynes, Karl Přibram, Edward Joseph Phelan, 1931.

http://books.google.com/books?id=zDFzEjOK5tgC\&printsec=frontcover\&dq=1931+harris+foundation+lecture $\underline{\mathrm{s} \& \mathrm{client}=\text { firefoxa\&source }=\mathrm{gbs} \text { book_other_versions_r\&cad }=0 \_1 \# \mathrm{v}=\text { onepage \&q }=1931 \% 20 \text { harris } \% 20 \text { foundatio }}$ $\underline{\mathrm{n} \% 20 l e c t u r e s \& \mathrm{f}=\text { false }}$

${ }^{8}$ http://www.imf.org/external/np/speeches/2009/090409.htm
} 
"I expect this recovery to be relatively sluggish. In the advanced economies, it is still largely driven by policy stimulus and restocking, with underlying private demand remaining weak. The outlook for the emerging economies is considerably better, though the pace of recovery in advanced trading partners remains a risk.

Given the fragility of the recovery, there are risks that it could stallthough thankfully these risks appear to be receding. Premature exit from accommodative monetary and fiscal policies is a principal concern. In addition, problems in the financial sector could persist or even intensify further, particularly if efforts to restore banks to health are not completed."

This looks right. And the inevitable consequence of a weak recovery is to delay further any sign of light in the labor market. In the next section, we look at the symptoms of the recession that are contributing to weakness in the labor market.

\section{Symptoms of Recession}

\section{1) Output}

The first lesson of labor economics is that labor is a derived demand, so it makes sense to begin by considering what has happened to output in recent quarters. Output has already fallen in many developed and less-developed countries. The extent of the decline in the G7 output is evident from Figure 2. It plots the deviation of G7 output from trend for the period 1961 to 2009 quarter $1 .^{9}$ By 2009Q1, output had fallen to almost 6\% below trend, having ended 2007 nearly $2 \%$ above trend. This deviation is substantially in excess of any recession in the last 50 years, leading to a concern that this recession will be deeper and longer lasting than previous downturns. The extent of the monetary contraction is historically large as is the scale of the fiscal and monetary responses.

But within this overall fall in OECD output, there is huge variation among countries, as again evidenced from Table 1. Table 2 gives the turning points of recession based on output. The variation between countries reflects differential levels of financial stress, differences in exposure to international trade, and variations in fiscal and monetary responses to the downturn. The fall in world trade has been much more rapid than that of world output. Hence, countries such as Germany and Japan, where external demand forms a large proportion of total demand, have experienced a more rapid decline in output than countries less dependent on trade. Trade in manufactures has fallen more rapidly than trade in services, perhaps because it is possible to trade from inventories with manufactures, but not with services.

One issue is when recession actually began around the OECD. There are two main places to look. First, using changes in GDP and/or secondly to the labor market. It is often asserted

\footnotetext{
${ }^{9}$ Data is detrended using the Hodrick-Prescott filter.
} 
that the labor market is a lagging indicator, but not this time in most countries. The NBER dating committee dated the start of the recession in the United States as being in December 2007. Their call was based on the change in the labor market, and principally on employment. In fact the unemployment rate started rising from around March 2007. Interestingly, output didn't start to fall until 2008Q2 in the United States. Of particular concern is that data revisions so far over the past year have suggested that the recession started earlier than first thought, for example in the UK, as revisions have been downward, in part due to the difficulties of seasonal adjustment.

Figure 3 shows more recent observations on some of the US data which the NBER used to time the beginning of the recession. The recent local minimum or maximum is indicated by a vertical red line. Data on house prices, unemployment, employment and real GDP are illustrated. Again, note that seasonal adjustment always introduces some noise into a data series, which may influence perceptions of turning points. However, Figure 3 does show an interesting set of correlations between data series, which may not be entirely causal, but which are certainly not coincidental.

House prices began to fall in 2006Q2, while unemployment started to rise in 2007. Two possible causal explanations are the negative wealth effects of declining house values on consumer demand and the reduction in activity in the construction sector. However, it appears that employment started to fall some time after unemployment began to increase. This may reflect supply characteristics.

Figure 4 illustrates the timing of the recession in Germany. It includes the same set of panels, other than house prices. The housing market is not implicated as a cause of the current difficulties in the German economy. The timing of the response to falling demand is more conventional in Germany than in the USA. Output starts to fall precipitously in $2008 \mathrm{Q} 1$. The decline in employment begins two quarters later and unemployment starts to rise after a further quarter's delay. This is a textbook response to a fall in demand, where firms initially try to hoard labor, particularly skilled labor, before initiating layoffs. However, the increase in unemployment in Germany is much smaller than that in the USA. This is not wholly explained by its later entry to recession. It also reflects different policy responses. Wage subsidies have been introduced in Germany, France, Italy and Spain to slow the increase in unemployment. The UK and USA have resisted such measures, partly because their social insurance schemes are much less generous than those in continental Europe, and therefore the net cost of such schemes would be much higher in the USA and UK.

Figure 5 and Figure 6 provide similar information on timing of the recession for France and the UK. Germany and France have experienced similarly modest reductions in employment. But output and unemployment in the two countries have behaved quite differently. Germany has experienced a much more significant fall in output, perhaps reflecting its greater dependence on exports as a source of demand. But unemployment has grown much more rapidly in France, which is surprising, given the similarity of the decline in employment in the two countries. This may stem from differences in the supply-side of the respective labor markets and from differences in policy responses to the recession. 
The pattern of events in the UK is much closer to the USA than either France of Germany. As with the USA, there was a very significant house price bubble in the UK prior to the recession. This came to an end in 2007 Q4, more than a year after the downturn in US house prices. Unemployment started to rise, and employment and output began to fall around 2007 Q4 and 2008 Q1. As in the USA, the rise in unemployment in the UK quickly exceeded the levels experienced during this decade, and now stands at its highest level since 1996. Thus far, unemployment in France and Germany remains below its previous peak in this decade.

\section{2) House Price Inflation}

Table 3 shows annual levels of house price inflation to the first quarter of 2009. It demonstrates how deep has been the fall in the price of housing in some countries. It shows that house-owners in the UK and USA have been among the hardest hit by the fall in value of what is likely to be their largest single asset. The Baltic Republics, with the exception of Lithuania, Poland, along with Ireland and Denmark have also experienced significant drops in value. On the other hand, there has been modest growth in values in some countries, such as Israel, the Czech Republic and Switzerland.

Changes in asset values will influence real behavior, as mentioned previously. Reductions in the value of housing will have wealth effects on consumers and will affect the construction sector. In addition, turnover is likely to fall if sellers price expectations are unrealistically high. This may impede efficiency as workers find it more difficult to migrate to take up new employment opportunities.

\section{3) The Labor Market}

Tables 4 and 5 contain information on the labor market response to the fall in demand. Table 4 shows the falls in employment and turning points. Countries are ranked by the percentage decline in employment from the peak. Up to the first half of 2009, Ireland, Spain and the United States experienced the greatest declines. As noted earlier the US went into recession on this measure in 2007 Q4, while Hungary entered even earlier in 2007 Q2. Most other countries entered recession in 2008 Q2. This includes the UK, Denmark, Italy, Portugal, and Turkey. France, Germany, Austria, Canada, the Czech Republic, Greece, Norway didn't see declining job numbers until the final quarter of 2008. By 2009Q1 all of the countries had declining employment.

The final column reports the relationship between the decline in employment and its scale compared with the size of the increase in unemployment since the peak. For example, in the United States employment has fallen by $5,684,000$ but unemployment has risen by 7,567,000 so the ratio in the final column is $75.1 \%$. In part this is why youth unemployment has risen so fast, firms have simply stopped hiring. We return to this issue below.

Table 5 contains similar information on unemployment. The most recent monthly unemployment rates for each OECD country are presented in Appendix Table 1 from January 2008-July 2009. It can be see from Table 5 that the turning point when unemployment started to rise is somewhat earlier than when employment started to fall. This occurred in 2007 in Spain, Ireland, the United States, Luxembourg, Japan and Italy. 
Unemployment rates started to rise in the G7 and the OECD in June 2007. In all of these countries unemployment was rising by the beginning of 2009 .

Table 6 brings together information from the goods market and the labor market. It shows the extent of the deterioration in employment and output since their most recent turning points for a range of countries. Countries are listed according to the fall in employment and output that they have experienced: less than 2 per cent; between 2 per cent and 4 per cent; and more than 4 per cent. The Baltic States and Ireland have experienced the most dramatic fall in demand, perhaps because their financial institutions were particularly exposed to the wholesale credit market. They have either not been able, or not been willing, to cushion the effects of the fall in demand on their respective labor markets and thus have experienced very large declines in employment. Spain has also experienced a very substantial fall in employment, though apparently without such a dramatic fall in employment. This may have arisen because demand falls have been concentrated in low productivity industries. It may also have been relatively easy for employers to reduce the size of their workforce, given that many workers in these industries are on temporary contracts and Spain has the highest concentration of workers on temporary contracts in Europe, at around 24 per cent of the workforce.

Some countries have largely been unaffected by the recession, because other factors offset the negative effects from demand. Thus countries like Norway and Australia may benefit from their production of natural resources where demand is relatively inelastic, while the Polish economy is benefiting from a reallocation of demand within Europe due to its relatively low costs. However, large numbers of migrant workers who worked in the UK and Ireland in particular have now returned, presumably to unemployment. As the remittances they sent home have presumably fallen considerably and which boosted the Polish economy in the past, this does not augur well for Poland in the next few years. Similar but smaller effects are likely to also be seen in Lithuania and Latvia where even higher proportions of the workforce went abroad, principally to the UK and Ireland, in search of work from 2004 when the A8 Accession countries joined the EU. The Dutch have had a relatively large drop in output of nearly five percentage points without much commensurate change to this point in either employment or unemployment. More recent evidence does suggest a considerable deterioration in the Dutch labour market.

The remaining countries have experienced larger falls in output than in employment: a mixture of labour hoarding by employers and the effects of policy measures taken by governments. Both of these effects may be time limited: employers may become unable to afford to hold on to staff unless there is a significant upturn in demand and governments may withdraw subsidies to employment due to worries about their fiscal stance.

Who has been impacted the most, by the rising levels of unemployment? The answer is the young, in every country. Table 7 shows the rise in youth unemployment rates from July 2008 to July 2009. Currently youth unemployment rates for the under $25 \mathrm{~s}$ in the Eu27 are 19.7\% and $17.8 \%$ in the United States. They are especially high in Spain $(38.4 \%)$. They are everywhere higher than adult rates. The next to last column gives the overall rate and the final column the ratio of youth: overall rates. Rates are two and a half times that of overall 
rates or more in Belgium, Finland, France, Hungary, Luxembourg, Slovenia, Sweden and the United Kingdom.

Table 8 provides some of the reason for this. The youth cohort is especially large at a time when the labor market is in the doldrums. The table sets out the size of four single age cohorts in comparison to the size of the cohort of twenty year olds, which is set to 100 . In some countries the number of twenty five year olds is a maximum, some it is other ages but this is done for simplicity. What we find is that a) in some Western countries the number of twenty year olds is greater than the number of twenty five year olds. Examples are the UK, Sweden, the Netherlands, Italy and Denmark that have very high youth unemployment rates. b) The big exceptions to that are in Eastern Europe (Armenia, Belarus, Estonia, Georgia, Latvia, Lithuania, Moldova, Romania, Russia and the Ukraine) that are well known to have declining birth rates and hence aging populations. c) However, very quickly the size of the youth cohort will collapse, especially in Eastern Europe. In five years time the number of twenty year olds, based on how many fifteen year olds there are now, declines rapidly, and even more so in ten and fifteen years time. The decline in the size of the cohort, in ten years time say, is smaller in the US than in other countries, in part because of the larger role of immigration. Immigrants tend to be young. In ten years time in the Euro area the number of twenty year olds will have dropped by twelve percent. In ten years time the size of the youth cohort is going to be smaller in all countries except Denmark, Luxembourg and Norway.

There is also some evidence from around the world, that the least educated, as well as those with the lowest skill levels, plus minorities and immigrants are especially impacted by the drop in demand. In the US for example, in August 2009, black unemployment rates stand at $15.1 \%$ and Hispanics at $13.0 \%$ compared with $8.9 \%$ for whites. ${ }^{10}$ Unemployment rates for high school dropouts were $15.6 \%$ compared with $9.7 \%$ for high school graduates, $8.2 \%$ for those with some college and $4.7 \%$ for those with a college degree and higher.

In the UK unemployment rates are much higher for the least skilled occupations. According to weighted data from the recently available UK 2009Q2 Labour Force Survey, unemployment rates by highest qualification were as follows.

$\begin{array}{lr}\text { Degree or equivalent } & 3.7 \% \\ \text { Higher degree } & 2.7 \% \\ \text { First degree } & 3.8 \% \\ \text { Other degree } & 3.3 \% \\ \text { Higher education } & 4.2 \% \\ \text { GCE A level or equivalent } & 7.3 \% \\ \text { GCSE grades A-C or equivalent } & 9.6 \% \\ \text { Other qualifications } & 10.7 \% \\ \text { No qualifications } & 14.4 \%\end{array}$

\footnotetext{
${ }^{10}$ Source: 'The employment situation', Bureau of Labor Statistics, August 2009. http://www.bls.gov/news.release/empsit.nr0.htm
} 
Unemployment rates, which average $7.7 \%$, by racial group were whites $7.1 \%$, mixed race 17.2\%; Asians 11.8\%, blacks 17.3\% and Chinese 4.2\%. The unemployment rate of those whose country of origin was outside the UK was $9.3 \%$. The distribution of UK occupations based on last occupation, is presented below in the first column for the unemployed along with the distribution of those currently employed in the second column. So $25.7 \%$ of the unemployed were employed in elementary occupations in their last job before they became unemployed, compared with $11.3 \%$ of the currently employed.

Managers and senior officials

Professional occupations

Associate professional and technical

Administrative and secretarial

Skilled trades occupations

Personal service occupations

Sales and customer service occupation

Process, plant and machine operatives

Elementary occupations

$\begin{array}{cc}\text { Unemployed } & \text { Employed } \\ 8.2 & 15.6 \\ 5.0 & 13.6 \\ 8.8 & 14.7 \\ 9.1 & 11.4 \\ 14.5 & 10.6 \\ 5.4 & 8.7 \\ 11.5 & 7.3 \\ 11.9 & 6.9 \\ 25.7 & 11.3\end{array}$

Note that the unemployed were more likely to be from elementary and skilled trade occupations and less likely to be from managerial or professional occupations.

According to the most recent Eurobarometer survey of individuals available \#70.1 which surveyed respondents in the EU27 between October and November 2008, the weighted EU27 average unemployment rates by education attainment suggested unemployment rates of $4.7 \%$ for individuals who left school at age 20 or higher and $9.0 \%$ for those who left school at a younger age. ${ }^{11}$ Unemployment rates were $7.6 \%$ for the indigenous populations and $11.1 \%$ for immigrants.

Table 9 provides evidence of unemployment rates by qualification across OECD countries. It is quite clear that for all age groups and countries, unemployment rates are higher for the least educated.

\section{Attitudes to Unemployment}

It is of interest to examine the attitudes of both individuals and firms at this stage in the cycle, not least because consumer and business confidence fell very early as countries moved into recession. In the USA consumer confidence started to fall around the middle of 2007, for example on the Conference Board balances presented below. It has recovered a little since the beginning of 2009 but remains at a low level.

$\begin{array}{llllll}\text { Jan-07 } & 110.2 & \text { Jan-08 } & 87.3 & \text { Jan-09 } & 37.4 \\ \text { Feb-07 } & 111.2 & \text { Feb-08 } & 76.4 & \text { Feb-09 } & 25.3 \\ \text { Mar-07 } & 108.2 & \text { Mar-08 } & 65.9 & \text { Mar-09 } & 26.9\end{array}$

\footnotetext{
${ }^{11}$ Data are available on approximately 25,000 individuals in the workforce.
} 


$\begin{array}{lrllll}\text { Apr-07 } & 106.3 & \text { Apr-08 } & 62.8 & \text { Apr-09 } & 40.8 \\ \text { May-07 } & 108.5 & \text { May-08 } & 58.1 & \text { May-09 } & 54.8 \\ \text { Jun-07 } & 105.3 & \text { Jun-08 } & 51.0 & \text { Jun-09 } & 49.3 \\ \text { Jul-07 } & 111.9 & \text { Jul-08 } & 51.9 & \text { Jul-09 } & 47.4 \\ \text { Aug-07 } & 105.6 & \text { Aug-08 } & 58.5 & \text { Aug-09 } & 54.1 \\ \text { Sep-07 } & 99.5 & \text { Sep-08 } & 61.4 & & \\ \text { Oct-07 } & 95.2 & \text { Oct-08 } & 38.8 & & \\ \text { Nov-07 } & 87.8 & \text { Nov-08 } & 44.7 & & \\ \text { Dec-07 } & 90.6 & \text { Dec-08 } & 38.6 & & \end{array}$

Consumer confidence in Europe also fell from the middle of 2007, predating the increase in the unemployment rate. Below we present data on the overall confidence indicator balances taken from the EU consumer confidence surveys. They also started to improve in 2009 even though the EU entered the recession several months after the US. However, it should be said that consumer confidence is still at low levels compared with the overall series average since January 1985 of minus 11 .

$\begin{array}{llllll}\text { Jan-07 } & -6 & \text { Jan-08 } & -10 & \text { Jan-09 } & -31 \\ \text { Feb-07 } & -5 & \text { Feb-08 } & -11 & \text { Feb-09 } & -32 \\ \text { Mar-07 } & -4 & \text { Mar-08 } & -11 & \text { Mar-09 } & -32 \\ \text { Apr-07 } & -4 & \text { Apr-08 } & -12 & \text { Apr-09 } & -28 \\ \text { May-07 } & -1 & \text { May-08 } & -13 & \text { May-09 } & -26 \\ \text { Jun-07 } & -1 & \text { Jun-08 } & -16 & \text { Jun-09 } & -23 \\ \text { Jul-07 } & -1 & \text { Jul-08 } & -20 & \text { Jul-09 } & -21 \\ \text { Aug-07 } & -3 & \text { Aug-08 } & -19 & \text { Aug-09 } & -20 \\ \text { Sep-07 } & -5 & \text { Sep-08 } & -19 & & \\ \text { Oct-07 } & -5 & \text { Oct-08 } & -24 & & \\ \text { Nov-07 } & -7 & \text { Nov-08 } & -26 & & \\ \text { Dec-07 } & -8 & \text { Dec-08 } & -29 & & \end{array}$

Tables 10 and 11 provide some evidence on people's views on changes they expect in the labor market. Table 10 is restricted to the United States. Part a) uses data from the University of Michigan surveys of Consumer Confidence. Here we report evidence on people's views on whether unemployment over the next twelve months will 'be more than now, the same or less'. Two main facts stand out. The fear of unemployment - measured by the proportion saying they expected it to rise, began to pick up from November 2007 just around the time the NBER dated the recession. It rose to $64 \%$, fell a little a year ago but was at $66 \%$ in January 2009 , the latest date we have data for. The story is broadly similar if we examine the proportion that say it would be less, until January 2009 when the proportion rose to $12 \%$.

Part b) of Table 10 provides comparable, and more timely, data for the United States from the Conference Board from January 2007 through August 2009. The series is available back to January 1978. Respondents were asked are jobs plentiful currently - responses are coded as plentiful, not so plentiful or hard to find. We also report the monthly US unemployment rate. As with the University of Michigan survey, the labor market appeared to start to 
slacken on these data ate the end of 2007. This is true whether we base it on the proportion of respondents in the 'plentiful' or 'hard to find' categories. The series has remained broadly stable as unemployment continued to increase during 2009.

US respondents seem to understand that unemployment is not going to improve much any time soon. Unfortunately respondents in Europe have a different view. They are much more optimistic that things are going to get much better when the evidence is to the contrary. This may well be a problem.

Responses are available in each member country of the EU each month to a very similar question to that asked in the Michigan survey. "How do you expect the number of people unemployed in the country to change over the next 12 months?" Answers are provided in five categories ranging from 'increase sharply' to 'decrease sharply. The series for the EU as a whole is reported in Figure 7 since its inception in 1985 as a survey balance. The series jumped sharply in mid-2007 well before unemployment started to rise, so people understood what was coming before the data showed it. We take the view there is something in these fear of unemployment series (Blanchflower, 1994, and Blanchflower and Shadforth, 2009). ${ }^{12}$ The fear of unemployment has helped to contain wage pressure.

However, just as unemployment started to rise rapidly from the beginning of 2009 (Appendix Table 1) in all countries, inexplicably, the fear of unemployment series improved. People appear to believe unemployment is going to improve. Why remains unclear. Respondents appear to believe the talk of green shoots. There is very little likelihood of that being the case according to most forecasts, including those of the OECD. Table 11 provides individual balances by country as well as how the balances are calculated. This phenomenon of a declining fear of unemployment, which is not present apparently in the USA, seems to be true in most countries except Latvia, Lithuania and Romania. This is likely to be a particular concern for policy makers if unemployment is rising and people don't expect that is going to be the case, especially as it interacts with falling house prices and negative equity. The fear of unemployment, it should be said, is still high historically across all countries.

Interestingly, despite the improvement in the fear of unemployment series in Europe by individuals there is less evidence that businesses have the same view. The EU also conducts a series of business monitors where it asks business owners for their views on a number of issues including how employment will change over the next three months. ${ }^{13}$ Separate surveys are conducted in construction, industry, retail and services. The survey balances for the EU27 are presented below.

12 Blanchflower, D.G. (1991). 'Fear, unemployment and pay flexibility', Economic Journal, March, pp. 483496. Blanchflower, D.G. and C. Shadforth (2009), "Fear, Unemployment and Migration", Economic Journal, 119(535), February, pp. F136-F182.

${ }^{13}$ Respondents were asked 'how do you expect your firm's total employment to change over the next 3 months? It will...+ increase; = remain unchanged - decrease'. 


$\begin{array}{lcccc} & \text { Building } & \text { Industry } & \text { Retail } & \text { Services } \\ \text { Jan-08 } & 4 & -2 & 5 & 10 \\ \text { Feb-08 } & 0 & -3 & 5 & 8 \\ \text { Mar-08 } & -1 & -3 & 4 & 10 \\ \text { Apr-08 } & -4 & -4 & 3 & 6 \\ \text { May-08 } & -4 & -6 & 1 & 8 \\ \text { Jun-08 } & -5 & -8 & -1 & 4 \\ \text { Jul-08 } & -9 & -11 & -3 & 4 \\ \text { Aug-08 } & -10 & -11 & -3 & 5 \\ \text { Sep-08 } & -13 & -13 & -4 & 3 \\ \text { Oct-08 } & -18 & -19 & -3 & -1 \\ \text { Nov-08 } & -20 & -24 & -5 & -5 \\ \text { Dec-08 } & -24 & -31 & -14 & -9 \\ \text { Jan-09 } & -31 & -34 & -18 & -16 \\ \text { Feb-09 } & -32 & -37 & -16 & -18 \\ \text { Mar-09 } & -31 & -41 & -16 & -21 \\ \text { Apr-09 } & -30 & -39 & -16 & -22 \\ \text { May-09 } & -28 & -38 & -13 & -22 \\ \text { Jun-09 } & -27 & -36 & -15 & -22 \\ \text { Jul-09 } & -27 & -33 & -13 & -23 \\ \text { Aug-09 } & -25 & -31 & -13 & -17\end{array}$

All of the surveys declined steadily from early 2008. There is little evidence of improved sentiment in any sector by businesses in 2009.

\section{The Consequences of Unemployment}

Bell and Blanchflower (2009) show that the major reasons why we care about unemployment are as follows: ${ }^{14}$

1) Because of the lost output involved. During a long period of unemployment, workers can lose their skills, causing a loss of human capital.

2) Unemployment is a stressful life event that makes people unhappy. ${ }^{15}$

3) Unemployment increases susceptibility to malnutrition, illness, mental stress, and loss of self-esteem, leading to depression. ${ }^{16}$ Goldsmith, Veum and Darity $(1996,1997)$ found, for

${ }^{14}$ D.N.F. Bell and D.G. Blanchflower (2009), 'What should be done about rising unemployment in the UK? Scotecon Working Paper available at http://www.dartmouth.edu/ blnchflr/papers/speech379paper.pdf

${ }^{15}$ L. Winkelmann and R. Winkelmann (1998), 'Why are the unemployed so unhappy? Evidence from panel data', Economica, 65(257), pp. 1-15. A.E. Clark and A.J. Oswald (1994), 'Unhappiness and unemployment', Economic Journal, 104(424), pp. 648-659. B.S. Frey and A. Stutzer (2002), Happiness and Economics, Princeton University Press. Ahn, N., J.R. García and J.F. Jimeno (2004), 'The impact of unemployment on individual well-being in the EU', European Network of Economic Policy Institutes, Working Paper No 29. 
example, using data from the NLSY that being jobless injures self-esteem and fosters feelings of externality and helplessness among youths. Moreover, they also found evidence that the psychological imprint of joblessness persists.

4) Increases in the unemployment rate tend to be associated with increases in the suicide rate. ${ }^{17}$ The unemployed appear to have a higher propensity to commit suicide.

5) Being unemployed can also reduce the life expectancy of workers. ${ }^{18}$

6) Unemployment increases the probability of poor physical health outcomes such as heart attacks in later life. ${ }^{19}$

${ }^{16}$ M. Linn, R. Sandifer and S. Stein (1985), 'Effects of unemployment on mental and physical health', American Journal of Public Health, 75, pp. 502-506. M. Frese and G. Mohr (1987), 'Prolonged unemployment and depression in older workers: a longitudinal study of intervening variables, Social Science and Medicine, 25, pp. 173-178. P. Jackson and P. Warr (1987), 'Mental health of unemployed men in different parts of England and Wales', British Medical Journal, 295, p. 525. M.H. Banks and P.R. Jackson (1982), 'Unemployment and the risk of minor psychiatric disorder in young people: cross-sectional and longitudinal evidence', Psychological Medicine, 12, pp. 789-798. Darity, W.R. Jr. and A.H. Goldsmith (1996), 'Social psychology, unemployment and macroeconomics', Journal of Economic Perspectives, 10(1), Winer, pp. 121-140. A.H. Goldsmith, J.R. Veum and W. Darity (1996), 'The psychological impact of unemployment and joblessness', Journal of SocioEconomics, 25(3), April, pp. 333-358. A.H. Goldsmith, J.R. Veum and W. Darity (1997), 'Unemployment, joblessness, psychological well-being and self-esteem: theory and evidence', Journal of Socio-Economics, 26(2), April, pp. 133-158. M.H. Brenner and A. Mooney (1983), Unemployment and health in the context of economic change', Social Science and Medicine, 17(16), pp. 1125-1138.

${ }^{17}$ S. Platt (1984), 'Unemployment and suicidal behaviour: a review of the literature', Social Science and Medicine, 19(2), pp. 93-115. C. Pritchard (1992), ' Is there a link between suicide in young men and unemployment? A comparison of the UK with other European Community Countries?', The British Journal of Psychiatry, 160, pp. 750-756. T.A. Blakely, S.C.D. Collings, J. Atkinson (2003), 'Unemployment and suicide. Evidence for a causal association?', Journal of Epidemiology and Community Health, 57, pp. 594-600. D.S. Hamermesh and N.M. Soss. 'An economic theory of suicide', Journal of Political Economy, January/February 1974, 82(1), pp. 83-98. D.G. Blanchflower and R.B. Freeman (2000), 'The Declining Economic Status of Young Workers in OECD Countries,' in D.G. Blanchflower and R.B. Freeman (editors), Youth Employment and Joblessness in Advanced Countries, University of Chicago Press and NBER. M.C. Daly, D.J. Wilson and N.J. Johnson (2008), ' Relative status and well-being: evidence from U.S. suicide deaths', Federal Reserve Bank of San Francisco Working Paper 2007-12.

http://www.frbsf.org/publications/economics/papers/2007/wp07-12bk.pdf

18 Brenner and Mooney (1984) ibid, K.A. Moser, P.O. Goldblatt, A.J. Fox and D.R. Jones (1987), 'Unemployment and mortality: comparison of the 1971 and 1981 longitudinal study census samples', British Medical Journal; 1, pp.86-90. K.A. Moser, P.O. Goldblatt, A.J. Fox and D.R. Jones (1990), 'Unemployment and mortality' in: Goldblatt P., editor. Longitudinal study: mortality and social organisation. London: OPCS, 1990. (Series LS No. 6.)

19 N. Beale and S. Nethercott (1987), 'The health of industrial employees four years after compulsory redundancy', Journal of the Royal College of General Practitioners, 37 pp. 390-394. L. Iverson and S. Sabroe (1988), 'Participation in a follow-up study of health among unemployed and employed people after a company closedown: drop outs and selection bias,' Journal of Epidemiology and Community Health, 42: 396-401. I. Mattiasson, F. Lindgarde, J.A. Nilsson and T. Theorell (1990), 'Threats of unemployment and cardiovascular risk factors: longitudinal study of quality of sleep and serum cholesterol concentrations in men threatened with redundancy', British Medical Journal, 301, pp. 461-466. 
7) The long-term unemployed are at a particular disadvantage trying to find work. ${ }^{20}$ The effects of unemployment appear to depend a lot on how long the person has been unemployed for. People's morale sinks as the duration of unemployment rises. Long-term unemployment is especially harmful. "The long-term unemployed have largely given up hope," (Layard, 1986, p.96). ${ }^{21}$

8) Unemployment while young, especially of long duration, causes permanent scars rather than temporary blemishes. ${ }^{22}$ For the young a spell of unemployment does not end with that spell; it raises the probability of being unemployed in later years and has a wage penalty. These effects are much larger than for older people.

9) As unemployment rates increase, crime rates tend to rise, especially property crime. ${ }^{23}$

10) Increases in the unemployment rate, lowers the happiness of everyone, not just the unemployed. The fear of becoming unemployed in the future lowers a person's subjective wellbeing. $^{24}$

The orthodox explanation of unemployment that argues that institutions matter has been subject to fairly extensive econometric testing, and in recent years, the validity of the

${ }^{20}$ S. Machin and A. Manning (1999), 'The causes and consequences of long-term unemployment in Europe', in Handbook of Labor Economics, Volume 3C, edited by O.C. Ashenfelter and D. Card, North Holland

${ }^{21}$ R. Layard (1986), How to beat unemployment, Oxford University Press.

${ }^{22}$ David Ellwood (1982), 'Teenage Unemployment: Permanent Scars or Temporary Blemishes?' in The Youth Labor Market Problem: Its Nature, Causes and Consequences, edited by Richard B. Freeman and David A. Wise, pp. 349-390. Chicago: University of Chicago Press, 1982

${ }^{23}$ T. Thornberry and R. Christensen (1984), 'Unemployment and criminal involvement. An investigation of reciprocal causal structures', American Sociological Review, 56, pp. 609-627. M. Lin (2008), 'Does unemployment increase crime? Evidence from US data, 1974-2000', Journal of Human Resources, 43(2), Spring, pp. 413-436. S. Raphael and R. Winter-Ebmer (2001), 'Identifying the effect of unemployment on crime', Journal of Law and Economics, 44(1), pp. 259-283. D. Fougere, F. Kramarz and J. Pouget (2006) 'Youth unemployment and crime in France', CEPR Discussion paper \# 5600. For a discussion of the relationship between unemployment and crime see R.B. Freeman (1999), 'The economics of crime', in Handbook of Labor Economics, Volume 3C, edited by O.C. Ashenfelter and D. Card, North Holland.

24 Di Tella R., MacCulloch R.J. and A.J. Oswald (2001), 'Preferences over inflation and unemployment: evidence from surveys of happiness', American Economic Review, 91, pp. 335-341. Di Tella R., MacCulloch R.J. and A.J. Oswald (2003), 'The macroeconomics of happiness', Review of Economics and Statistics, 85, 809-827. D. G. Blanchflower (2007), 'Is unemployment more costly than inflation?', NBER Working Paper W13505, October. D.G. Blanchflower, David (1991), 'Fear, unemployment and pay flexibility', Economic Journal, 101, pp. 483-496. A. Knabe and S. Rätzel (2008), 'Scarring or scaring? The psychological impact of past and future unemployment', Otto-von-Guericke-University Magdeburg, February 21. 
empirical results supporting this view has been called into question. ${ }^{25}$ It has proved difficult to estimate a set of cross-country panel unemployment regressions that contain a lagged unemployment rate and a full set of year and country dummies and show that any of the labor market rigidity variables work. This is a crucial test.

This is the first main similarity between European labor markets: labor market institutions do not tend to cause unemployment. The major exception is changes in the replacement rate, which, in some specifications, do appear to be negatively correlated with changes in the unemployment rate. Blanchard and Wolfers (2000) have argued that "the interaction of shocks and institutions does a good statistical job of fitting the evolution of unemployment both over time and across countries." This result is questionable because it is obtained in an over-fitted model - few data points and lots of variables - and the results appear to be driven by the cross-section variation rather than by any time series changes. ${ }^{26}$ There are only eight time series data points as they use five-year averages from 1960-1995. Unfortunately this explanation does a terrible job of explaining the growth in unemployment across countries in the current crisis.

In a recent article, Howell et al (2007) econometrically examined the impact of these rigidity variables, or what they call Protective Labor Market Institutions (PLMIs), and concluded that: "while significant impacts for employment protection, benefit generosity, and union strength have been reported, the clear conclusion from our review of these studies is that the effects for the PLMIs is distinctly unrobust, with widely divergent coefficients and levels of significance." Indeed, in his published comments on the Howell et al. article, Jim Heckman (2007) argues that the authors "... are convincing in showing the fragility of the evidence on the role of labor market institutions in explaining the pattern of European unemployment, using standard econometric methodology." Freeman (2007) also finds the evidence for the impact of these institutional variables less than convincing "despite considerable effort, researchers have not pinned down the effects, if any, of institutions on other aggregate economic outcomes, such as unemployment and employment". ${ }^{27}$ In a recent article, Horst

25 R. Layard, S.N. Nickell and R. Jackman (2005), Unemployment, macroeconomic performance and the labour market, Oxford University Press, $2^{\text {nd }}$ edition. S.N. Nickell (2006), 'A picture of European unemployment: success and failure', in Structural unemployment in Western Europe, edited by M. Werding, CESifo Seminar Series, MIT Press, Cambridge, MA.

${ }^{26}$ Blanchard, O., and Wolfers, J. (2000), 'The role of shocks and institutions in the rise of European unemployment: The aggregate evidence', Economic Journal, 110 (462), pp. 1-33.

${ }^{27}$ D. Howell, D. Baker, A. Glyn and J. Schmitt (2007), 'Are protective labour market institutions at the root of unemployment? A critical review of the evidence', Capitalism and Society, 2(1), pp. 171. Heckman, J. (2007), 'Comments on 'Are protective labour market institutions at the root of unemployment? A critical review of the evidence by David Howell, Dean Baker, Andrew Glyn and John Schmitt', Capitalism and Society, 2(1), Article 5, pp. 15. R.B. Freeman (2007), 'Labor market institutions around the world', NBER WP\#13242. Blanchflower, D.G. (2001), 'Unemployment, wellbeing and wage curves in Eastern and Central Europe', Journal of the Japanese and International Economies, 15(4), pp. 364-402. 
Feldmann examined how the quality of industrial relations affects unemployment in developing countries and found relatively moderate effects, especially for females. ${ }^{28}$

Countries that have had big increases in unemployment have been either exposed to world trade (Germany, Japan and Sweden) or had large increases in house prices (Spain, Ireland and the UK) or had large financial sectors (UK and the USA). The explanations for unemployment rest in capital, product and housing markets and not in labor markets. Countries with low unionization rates such as the United States and Korea as well as ones with high rates such as Denmark, Sweden and Norway have also done badly.

\section{Youth Unemployment}

There is a considerable body of evidence suggesting that the young, the least educated and especially minorities are hardest in a recession. ${ }^{29}$ Youth unemployment rates continue to be more sensitive to business-cycle conditions than the adult unemployment rate, as many studies have shown (OECD, 2008). ${ }^{30}$ Young unskilled men from minority groups are thus particularly hard hit. This is true around the world.

Clark and Summers (1982), in their classic study of the dynamics of youth joblessness argue that the problem of teenage unemployment arises from a shortage of jobs. "Aggregate demand has a potent impact on the job prospects and market experience of teenagers" (1982, p.230). ${ }^{31}$ Freeman and Wise (1982), for example, found in their study of youth joblessness in the 1970s that it was concentrated, by and large, among a small group who lacked work for extended periods of time. ${ }^{32}$ Over half of the male teenage unemployment they examined was among those who were out of work for over six months, a group constituting less than $10 \%$ of the youth labor force and only $7 \%$ of the youth population. The youths who make up the relatively small group that was chronically without work Freeman and Wise reported had distinct characteristics. They were disproportionately black; disproportionately high school dropouts, and disproportionately residents of poverty areas.

\footnotetext{
${ }^{28} \mathrm{H}$. Feldmann (2009), 'The quality of industrial relations and unemployment in developing countries', $\underline{\text { Review }}$ of Development Economics, 13(1), pp. 56-69.

${ }^{29}$ D.G. Blanchflower and R.B. Freeman (editors), Youth Employment and Joblessness in Advanced Countries, University of Chicago Press and NBER, 2000 and Freeman, R. B. and D. A. Wise, (editors), The Youth Labor Market Problem: Its Nature, Causes, and Consequences, University of Chicago Press and NBER, 1982.

30 OECD (2008a), 'Off to a good start? Youth labour market transitions in OECD countries', OECD Employment Outlook, 2008, pp. 25-77, Paris, France.

${ }^{31}$ K.B. Clark and L.H. Summers (1982) 'The dynamics of youth unemployment' in Freeman, R. B. and D. A. Wise, (editors), The Youth Labor Market Problem: Its Nature, Causes, and Consequences, University of Chicago Press and NBER.

${ }^{32}$ Richard B. Freeman and David A. Wise (1982), 'The youth labor market problem: its nature causes and consequences:' in Freeman, R. B. and D. A. Wise, (editors), The Youth Labor Market Problem: Its Nature, Causes, and Consequences, University of Chicago Press and NBER.
} 
Blanchflower and Freeman (2000) identified one basic pattern in the job market for young workers: the disproportionately large response of youth employment or unemployment to changes in overall unemployment. ${ }^{33}$ They argued that the sensitivity of youth employment and unemployment to the overall rate of unemployment dominate sizable demographic and structural changes favorable to youth in determining how youths fare in the job market. This was also confirmed in Blanchflower and Freeman (1996) and Makeham (1980). ${ }^{34}$ Recently OECD (2008a) confirmed this conclusion "Youth unemployment rates are more sensitive to business-cycle conditions than the adult unemployment rate and this high-sensitivity tends to decline progressively with age". ${ }^{35}$

There is also evidence that young people do especially well in booms. Freeman and Rodgers (1999) who analyzed the 1990s boom in the United States and found that it substantially improved the position of non-college educated young men, especially young African Americans who are the most disadvantaged and troubled group in the US. ${ }^{36}$ Young men in tight labor markets experienced a substantial boost in both employment and earnings. Adult men had no gains and their earnings barely changed even in areas where unemployment rates were below 4\%. Youths did particularly well in areas that started the boom at lower jobless rates suggesting they would "benefit especially from consistent full employment" (Freeman and Rodgers, 1999, p.2). As unemployment amongst the young goes down and the attractiveness of work increases, because there are more jobs and better paying jobs out there and it becomes a virtuous cycle. Freeman and Rodgers found evidence that once that occurred in the US the crime rate dropped. Increase aggregate demand and youths, especially disadvantaged youths, seem to do best

OECD (2008a) presented evidence on youth (20-24) earnings relative to adult earnings across countries. The evidence is presented below and suggests that a) this ratio in the UK has fallen over time and b) now is below the OECD average but was above it in 1996.

$\begin{array}{lll} & 2006 & 1996 \\ \text { Australia } & .73 & .74 \\ \text { Canada } & .64 & .62 \\ \text { Denmark } & .65 & .72 \\ \text { Finland } & .68 & .70\end{array}$

${ }^{33}$ D.G. Blanchflower and R.B. Freeman (2000).

${ }^{34}$ D.G. Blanchflower and R.B. Freeman (1996), 'Growing into Work: Youth and the Labour Market over the 1980s and 1990s', OECD Employment Outlook, OECD, Paris and P. Makeham (1980), 'Youth unemployment. An examination of evidence on youth unemployment using national statistics', Department of Employment Research Paper No. 10, London.

35 OECD (2008a), 'Off to a good start? Youth labour market transitions in OECD countries', $\underline{\text { OECD }}$ Employment Outlook, OECD, Paris.

36 Freeman, R.B. and W.M. Rodgers (1999), 'Area economic conditions and the labor market outcomes of young men in the 1990s expansion’, NBER Working Paper \#7073, Cambridge, MA. 


$\begin{array}{lll}\text { Germany } & .61 & .62 \\ \text { Ireland } & .67 & .61 \\ \text { Japan } & .60 & .62 \\ \text { New Zealand } & .75 & .75 \\ \text { Sweden } & .68 & .73 \\ \text { UK } & .60 & .68 \\ \text { USA } & .57 & .58 \\ \text { OECD } & .64 & .67\end{array}$

Interestingly, such evidence there is that the high relative wages of the young being responsible for pricing them out of the jobs comes only from the 1970s. Interestingly, that is the period of most rapid increase in union activity. Union membership peaked in the 1970s with union density - the proportion of workers who are members of trade unions - at a little over $50 \%$ (Lindsay, 2003). Since that time union membership numbers and density rates have fallen. In 2007 union density had fallen to $25 \%$ and $15.9 \%$ among private sector British employees. Unions generally operate rates for the job, which would have the effect of raising the relative wage of the young, and hence making them relatively less attractive, and then lowering their employment.

In an important early contribution Ellwood (1982) examined the persistence and long-term impacts of early labor force experiences. The paper reports a rise in employment rates for a cohort of young men as they age, but points out that those persons with poor employment records early have comparatively poor records later. The paper found that the effects of a period without work do not end with that spell. A teenager who spends time out of work in one year will probably spend less time working in the next than he would have had he worked the entire year. Furthermore, the lost work experience Ellwood concluded were reflected in considerably lower wages. The reduced employment effects Ellwood examined appeared to die off very quickly. What appeared to persist were effects of lost work experience on wages. More recently Mroz and Savage (2006) reached a similar conclusion using data from the NLSY for the US and also found evidence of long-lived blemishes from unemployment. A six month spell of unemployment at age 22 would result in an 8 per cent lower wage at 23 and even at ages 30 and 31 wages were 2-3 per cent lower than they otherwise would have been. Kletzer and Fairlie (1999) also using data for the US estimate that for young unemployed workers the costs of job loss in terms of annual earnings are $8.4 \%$ and $13.0 \%$, for boys and girls, respectively. ${ }^{37}$

Gregg and Tominey (2005) found using data from the NCDS for the UK that there was a significant wage penalty of youth unemployment even after controlling for education, region and a wealth of family and personal characteristics. Their results suggested a scar from youth unemployment of $13-21 \%$ age 41 although this penalty was lower at $9-11 \%$ if

37 T.A. Mroz and T.H. Savage (2006), 'The long-term effects of youth unemployment', Journal of Human Resources, Spring, 41(2), pp. 259-293. R. Fairlie and L.G. Kletzer (2003), 'The long-term costs of job displacement among young workers,' Industrial and Labor Relations Review, 56(4), pp. 682-698. 
individuals avoid repeat exposure. ${ }^{38}$ Gregg (2001) also used NCDS data to show that unemployment experience up to the age of 23 drives unemployment in subsequent years. ${ }^{39}$

Arulampalam (2001) found that joblessness leaves permanent scars on people and reduces the probability of employment and future earnings and increases the risk of future unemployment. She found that a spell of unemployment carries a wage penalty of $6 \%$ on reentry in Britain, and after three years, they are earning 14\% less compared to what they would have received absent unemployment. Arulampalam et al (2000) also found evidence of unemployment persistence, especially for young men. Narendranathan and Elias (1993) also find evidence of state dependence and report that 'the odds of becoming unemployed are 2.3 times higher for youths who were unemployed last year than for youths who were not unemployed' (p.183). Arulampalam et al. (2001) also report that the best predictor of an individual's future risk of unemployment is his past history of unemployment. They find that unemployment has a scarring effect for both future unemployment and future earnings. In addition Burgess et al. (1999) find that unemployment while young raises the probability of subsequent unemployment, but the size of any effect varies by skill level. ${ }^{40}$

Bell and Blanchflower (2009) found, using data from the British birth cohort the NCDS that youth unemployment continues to hurt two decades later on a variety of variables including unemployment, health status, wages and job satisfaction in contrast to unemployment when in one's early thirties. As we will see, there are permanent scars from youth unemployment. A spell of unemployment when young continues to have a harmful impact in later life. Youth unemployment is harmful and needs to be avoided.

So we need to deal with unemployment with a particular focus on the young. The youth cohort is currently large. It is time to act to ensure they are not a lost generation.

\section{Policy Measures}

It seems to us that there are a number of measures that can be taken to deal with the crisis.

\section{i) Maintain or even increase aggregate demand}

\footnotetext{
${ }^{38}$ P.A. Gregg and E. Tominey (2005), 'The wage scar from male youth unemployment', Labour Economics, 12, pp. 487-509

${ }^{39}$ P. Gregg (2001), 'The impact of youth unemployment on adult unemployment in NCDS', Economic Journal, 111(475), pp. F623-F653.

${ }^{40}$ W. Arulampalam (2001), 'Is unemployment really scarring? Effects of unemployment experiences on wages', Economic Journal, (111), November, pp: F585-F606. W. Narendranathan and P. Elias (1993), 'Influences of past history on the incidence of youth unemployment: empirical findings for the UK', Oxford Bulletin of Economics and Statistics, 55, pp. 161-185. W. Arulampalam, A. Booth and M. Taylor (2000), 'Unemployment persistence', Oxford Economic Papers, 52, pp. 24-50. S. Burgess, C. Propper, H. Rees and A. Shearer (2003), 'The class of 1981: the effects of early career unemployment on subsequent unemployment experiences, Labour Economics, 10(3), June, pp. 291-309. For a useful summary of the school to work transition see S. Bradley and Nguyen, A.N. (2004), 'The school-to-work transition'. In: G. Johnes and J. Johnes (Eds.), International Handbook on the Economics of Education. Edward Elgar, Cheltenham, Glos.
} 
The main issue in the current recession is the lack of demand. Unemployment has not risen because people have chosen to be unemployed. Unemployment is largely involuntary. The reserve army of the unemployed is a conscript army and not a volunteer army. Unemployment makes people unhappy. It lowers the happiness of the people who are unemployed but it also lowers the happiness of everyone else. Rising unemployment lowers well-being more than rising inflation. ${ }^{41}$

In its 2009 Economic Outlook the OECD forecast unemployment rates for 2010 as follows. We also present the latest unemployment rates from the OECD website.

$\begin{array}{lrrlrr} & 2010 & 2009 & & 2010 & 2009 \\ \text { Australia } & 7.7 & 5.8 & \text { Luxembourg } & 7.2 & 6.4 \\ \text { Austria } & 7.9 & 4.4 & \text { Mexico } & 6.9 & 5.7 \\ \text { Belgium } & 10.6 & 8.0 & \text { Netherlands } & 7.0 & 3.4 \\ \text { Canada } & 9.8 & 8.6 & \text { New Zealand } & 7.9 & 6.0 \\ \text { Czech Republic } & 9.2 & 6.4 & \text { Norway } & 4.3 & 3.1 \\ \text { Denmark } & 7.9 & 5.9 & \text { Poland } & 11.6 & 8.2 \\ \text { Finland } & 10.8 & 8.7 & \text { Portugal } & 11.2 & 9.2 \\ \text { France } & 11.2 & 9.8 & \text { Slovak Republic } & 13.6 & 12.0 \\ \text { Germany } & 11.6 & 7.7 & \text { Spain } & 19.6 & 18.5 \\ \text { Greece } & 10.3 & 8.7 & \text { Sweden } & 11.4 & 9.2 \\ \text { Hungary } & 11.7 & 10.3 & \text { Switzerland } & 5.1 & 4.1 \\ \text { Iceland } & 9.9 & 7.0 & \text { United Kingdom } & 9.7 & 7.7 \\ \text { Ireland } & 14.8 & 12.5 & \text { United States } & 10.1 & 9.7 \\ \text { Italy } & 10.2 & 7.4 & \text { Euro area } & 12.0 & 9.5 \\ \text { Japan } & 5.7 & 5.7 & \text { Total OECD } & 9.8 & 8.5 \\ \text { Korea } & 3.9 & 3.8 & & & \end{array}$

Unemployment rates are predicted to increase a lot further in most countries. The main exceptions are Japan and South Korea. They are predicted to be above ten percent in Belgium, Finland, France, Germany, Greece, Hungary, Ireland, Italy, Poland, Portugal, teh Slovak Republic, Spain, Sweden, the USA and the Euro area as a whole. Unemployment levels of this kind have not been seen for a number of decades. If there is a double-dip recession these will be under-estimates.

It appears that unemployment rates are especially high among minorities, the least skilled and the young. The fear is that these high levels of unemployment will generate social unrest and rising levels of crime, especially property crime. We need to act to prevent this.

The fiscal and monetary authorities across the OECD have implemented dramatic loosening of policy. Interest rates have come down to historically low levels. Central banks have moved to quantitative easing, increasing the supply of money. There have been various kinds of fiscal stimuli directed at jobs including the American Recovery and Reinvestment

\footnotetext{
${ }^{41}$ Blanchflower $(2007,2009)$.
} 
Act of 2009. The various 'cash for clunkers' and 'cash for bangers' programmes appear to have at least temporarily increased the demand for cars. The worry is that demand will now start to fall again once the programs have ceased.

There is still the issue in many countries that banks are not lending enough and the gap left by foreign and secondary lenders that have withdrawn have yet to be dealt with. The interaction between rising unemployment and negative equity is likely to present a further difficulty in a number of countries. The question is to what extent have the problem of toxic assets been dealt with. The worry is that there is a lot more to come and forecasts are overly optimistic. Forecasters missed the recession on the way down and may well be too optimistic on the way up. There is still a fear of a Japan type lost decade.

Withdrawing fiscal and monetary stimulus too early is likely to kill off any budding shoots. Winter approaches.

\section{ii) Target assistance on the young}

We have indicated that a significant rise in unemployment is likely during 2009 and 2010 at least. Young workers are especially vulnerable to a rise in unemployment. So what kinds of policies might be worth considering, in order to dissipate these costs?

\section{a) Active Labour Market Programs}

There is a substantial body of literature that analyses the effectiveness of labour market policies for the young. This work is summarized in Bell and Blanchflower (2008). In Europe there seems to be little evidence that active labor market policies have had a positive impact on participants' wages. There is stronger evidence that they have had positive employment effects but there is no consensus on the question. Even if there were, it is unclear the extent to which any of the newly created jobs constitute net job creation or are offset by the displacement of non-participants. In 1996 when asked how much training schemes in the US help their clientele Nobel Laureate Jim Heckman replied that 'zero is not a bad number' (Economist, $6^{\text {th }}$ April, 1996).

In our view there is little evidence to support large scale, active labour market programs to help the young or any other group. In a recession when unemployment rates are high job placement rates from any ALMP are likely to plummet and the schemes are unlikely to provide adequate rates of return.

\section{b) Expansion of education.}

A traditional response of young people in recessions is to withdraw from the labour force. Applications to colleges and universities rise. This is a sensible response and to be encouraged. Temporary expansion iof the number of places in higher and tertiary education makes sense. Possibilities exist to also encourage young people to remain in high school, perhaps with financial inducements. Given the declining size of the youth cohort any expansion in the numbers is likely to be temporary as a) the numbers fall b) the recession recedes.

c) Wage/employment subsidies for the young 
Given the evidence that a spell of unemployment while young has especially harmful effects there is an argument to provide subsidies to private sector firms to hire them. This could take the form of a subsidy for every additional new worker hired. The concern would be that older workers would be fired but the subsidy should be based on additional net hires.

d) Incentives for hiring the young in public sector organisations such as in education and health

One possibility would be to allow public sector organisations to hire young people for say, two years, and pay them the equivalent of the benefits they would have received on unemployment benefits. This would be subsidized training.

\section{e) Lowering the minimum wage for the young.}

Where the minimum wage is high there is an argument to have it lowered. The issue is whether there is evidence that it is a binding constraint. One possibility would be to temporarily remove it for anyone under age 25 , for two years.

\section{iii) Other measures}

Governments around the world have responded to the unemployment crisis with a variety of fiscal measures. Perhaps the most well known example is the American Recovery and Reinvestment Act of 2009 (Recovery Act), which was signed into law by President Obama on February 17th, 2009. According to the US Department of Labor the Act includes "measures to modernize the infrastructure, enhance energy independence, expand educational opportunities, preserve and improve affordable health care, provide tax relief, and protect those in greatest need". ${ }^{42}$ As is made clear in an interesting report by the European Foundation for the Improvement of Living and Working Conditions, there have been a variety of 'anti-crisis' packages in European countries. ${ }^{43}$ Measures in other countries have included the following.

i) Training and non-dismissal requirements (e.g. Austria and Luxembourg).

ii) Use of short-time work or temporary layoff (e.g. France, Germany, Sweden, Denmark and Belgium).

iii) Reductions in social security contributions (e.g. Germany, Bulgaria, Slovenia and Portugal).

iv) Tax exemptions or deferrals for enterprises (e.g. Belgium and the Netherlands).

v) Income tax cuts (e.g. Latvia, Italy and Poland).

vi) VAT tax cuts (e.g. UK).

vii) Direct and indirect enterprise support (Estonia, France, Italy, Sweden and Poland).

viii) Job matching, counseling and career guidance (e.g. Sweden and the UK).

ix) Incentives for companies to employ additional workers especially from vulnerable groups (e.g. France, Slovenia and the UK).

x) Retraining of unemployed people (e.g. France and the Netherlands).

\footnotetext{
${ }^{42}$ http://www.dol.gov/recovery/

${ }^{43}$ 'Tackling the recession: Employment related public initiatives in the EU Member States and Norway', European Foundation for the Improvement of Living and Working Conditions, 2009. See http://www.eurofound.europa.eu/docs/erm/tn0907020s/tn0907020s.pdf
} 
xi) Mobility grants (e.g. Belgium and the Czech Republic).

xii) Supporting self-employment including funding for business start-ups (e.g. Romania, Bulgaria, Austria and the UK).

xiii) Extension of the duration of unemployment benefits e.g. USA.

The difficulty is that there are simply insufficient jobs available. This means that measures such as retraining, mobility grants and counseling are unlikely to be successful on their own. At the very least they will not be as successful as they were when unemployment was low. Expansion of self-employment may well get unemployment down but doesn't deal with the problem that there is little work out there so earnings may well be very low. Architects aren't finding much work currently. Directly stimulative measures are likely to be most successful including use of short-time work subsidies, tax exemptions, tax cuts and incentives to employ additional workers. The exact choice will depend on a particular country's needs. It is likely to be important going forward to ensure adequate access to capital for firms. This is likely to be of particular concern for small firms. Despite the existence of all of these various measures unemployment continues to rise apace. It clearly would have been worse absent the programs, but they are clearly not enough.

The loss of output associated with this slump may be permanent in some developed countries, in which case the price of labour may have to fall in the longer-run in order to return to full employment. For those countries with a substantial fiscal deficit, downward pressure on wages is likely to be strongest in the public sector. But these are longer term objectives of policy which should only be addressed once recovery is secure.

\section{Conclusion}

The recession has hit right across the world, with consequent adverse effects on the demand for labor. The effects on output have varied across countries, depending on asset bubbles, imbalances in private or government debt and trade imbalances.

Governments have generally reacted by stimulating demand through fiscal measures, thus partly offsetting the fall in private sector demand caused by credit restrictions and the loss of consumer and business confidence. Central banks around the world, including the Federal Reserve, the Bank of England, the ECB and the Sveriges Riksbank, have cut interest rates close to zero and engaged in quantitative easing for the first time since the 1930s to get their various economies moving again in the face of a threat of deflation.

Some countries have intervened more decisively than others in the labor market. Measures to subsidizes those in work have reduced redundancy levels are maintained demand particularly in countries where the replacement ratio is low. The ILO has estimated that without discretionary fiscal measures and the effects of automatic stabilizers, unemployment would have been between 7 and 11 million higher in the G20 countries during 2009.

Thus far, at a country level, increases in unemployment have not been closely related to falls in output. In some countries, the increase in unemployment has far exceeded the reduction in output. This may reflect increases in labor supply, large-scale redundancies among low skilled workers and/or barriers to adjustment of labor inputs that fall short of redundancy. 
The countries that experienced the largest increases in unemployment tended to experience asset bubbles that peaked in 2006 or 2007. Unemployment has risen rapidly in Spain, USA, Ireland and the Baltic States. Countries that were over-reliant on exports (e.g. Germany and Japan) have experienced large falls in output, but increases in unemployment have been moderate, perhaps because of policy interventions or because management has decided to hoard labor.

Historic evidence suggests that financial crises have a long-term negative effect on economic growth. With a severe crisis, the fall could amount to a permanent reduction of output of as much as $4 \%$. This will inevitably impact the demand for labor. In these circumstances, engineering a return to full employment will be a huge challenge for the policy community. It is not clear that the supply-side policies that were popular in the 1990s and early part of this decade will form part of the solution. Perhaps further extension of the job saving measures that have been implemented may be necessary to maintain demand, albeit at the cost of higher government debt. Moves to cut public expenditure as suggested by some political groups, deep in a recession are a mistake. The danger is that they will turn a recession into a depression. As Keynes' biographer Lord Robert Skidelsky has noted recently there is no reason why this should become a depression. ${ }^{44}$

"How long will the slump last? This is the worst global turndown since the Great Depression. But it is highly unlikely to be as bad. The years 1929-32 saw twelve successive quarters of economic contraction. If repeated, this would mean the economic slide will continue till mid 2011. But the present contraction will be neither as deep nor as long and this for two reasons. First, the will to international cooperation is stronger. Second, we do have Keynes. To be a Keynesian in the 'foxhole' is not enough. But it is better than to be a classical economist in the foxhole, which was the only intellectual support that perplexed policymakers had available during the Great Depression. Governments at that time made heroic efforts to balance their budgets: they allowed banks to fail and households to default on their mortgages; they stuck to the gold standard which kept interest rates high for the first two years of the slump. Today the intellectual climate is different. The 'stimuli', which have been put in place, will stop the slide into another Great Depression. The financial system will be cleaned up, and money will become very cheap, but the collapse of confidence will continue to depress new investment for years ahead." (Skidelsky 2009, p.15)

and later.

"Keynes's big idea was to use macroeconomic policy to maintain full employment. His specific suggestion was to use monetary policy to secure a permanently low interest rate and fiscal policy to achieve a continuously high level of public or semi-public investment. Over time, as the returns on further additions to capital fell, the high-investment policy should yield to the

\footnotetext{
${ }^{44}$ Robert Skidelsky (2009), Keynes. The return of the master. Public Affairs, New York.
} 
encouragement of consumption through redistributing income from the higher to the lower-saving section of the population. This should be coupled with a reduction in the hours of work. In short, the object of macro-policy should be to keep the economy in 'quasi-boom' till the economic problem was solved and people could live 'wisely, and agreeably, and well'. (Skidelsky 2009, p.179).

We are not at that point yet of quasi-boom. We are still experiencing the dragging conditions of semi-slump.

Policy makers around the world appear to have understood this need for stimulus. What has been absent from the policy response thus far, though, is a coherent approach to the treatment of younger people who have not yet entered the labor market. We know that these are particularly vulnerable individuals, whose long-term opportunities can be damaged by adverse events early in their labor market experience. We also understand that the discounted social and health costs associated with youth unemployment are extremely high. It is thus extremely important to introduce policies which enhance the skills and capabilities of younger workers and which assist them to join the labor market as quickly as possible. Spells of unemployment while young create permanent scars. Unemployment is higher in the years ahead if a young person doesn't make a successful toe-hold into the labour market early in their lives. Solving youth unemployment is the most pressing problem governments are facing today. Not dealing with the problem of high, and rising levels of youth unemployment hurts the youngsters themselves and has potentially severe consequences for us all for many years to come. The time to act is now. The young must be the priority. 
Table 1. Change in Output from 2008 Quarter 3 to 2009 Q2.

\begin{tabular}{|c|c|c|c|c|c|c|c|c|}
\hline & \multicolumn{4}{|c|}{$\begin{array}{c}\text { Percentage change compared with the } \\
\text { previous quarter }\end{array}$} & \multicolumn{4}{|c|}{$\begin{array}{c}\text { Percentage change compared with } \\
\text { the same quarter of the previous } \\
\text { year }\end{array}$} \\
\hline & 2008 & 2008 & 2009 & 2009 & 2008 & 2009 & 2008 & 2009 \\
\hline & Q3 & Q4 & Q1 & Q2 & Q3 & Q4 & Q1 & Q2 \\
\hline EA16 & -0.3 & -1.8 & -2.5 & -0.1 & 0.5 & -1.7 & -4.9 & -4.7 \\
\hline EU27 & -0.4 & -1.9 & -2.4 & -0.2 & 0.7 & -1.7 & -4.8 & -4.8 \\
\hline Austria & -0.3 & -1.0 & -2.7 & -0.4 & 2.2 & 0.2 & -3.5 & -4.4 \\
\hline Belgium & 0.0 & -1.7 & -1.7 & -0.4 & 1.1 & -1.0 & -3.1 & -3.8 \\
\hline Cyprus & 0.1 & 0.2 & -0.6 & -0.5 & 3.3 & 2.5 & 0.8 & -0.7 \\
\hline Czech Republic & 0.6 & -1.8 & -3.4 & : & 3.1 & -0.1 & -3.4 & $:$ \\
\hline Denmark & -0.9 & -2.0 & -1.1 & $:$ & -1.7 & -3.7 & -4.3 & $:$ \\
\hline Estonia & -2.8 & -5.3 & -6.1 & -3.7 & -3.5 & -9.7 & -15.1 & -16.6 \\
\hline Finland & -0.9 & -2.1 & -2.7 & $:$ & 0.7 & -2.6 & -6.0 & $:$ \\
\hline France & -0.2 & -1.4 & -1.3 & 0.3 & 0.1 & -1.6 & -3.4 & -2.6 \\
\hline Germany & -0.3 & -2.4 & -3.5 & 0.3 & 0.8 & -1.8 & -6.7 & -5.9 \\
\hline Greece & 0.4 & 0.3 & -1.2 & 0.3 & 2.7 & 2.4 & 0.3 & -0.2 \\
\hline Hungary & -1.0 & -1.9 & -2.6 & -2.1 & 0.3 & -2.2 & -5.6 & -7.4 \\
\hline Iceland & 2.9 & -0.9 & -3.6 & : & $\begin{array}{l}-1.3 \\
\end{array}$ & -1.3 & -3.3 & : \\
\hline Ireland & 0.6 & -5.4 & -1.5 & : & -1.2 & -8.0 & -8.4 & $:$ \\
\hline Italy & -0.8 & -2.1 & -2.7 & -0.5 & -1.3 & -3.0 & -6.0 & -6.0 \\
\hline Japan & -1.0 & -3.5 & -3.1 & 0.9 & -0.3 & -4.5 & -8.3 & -6.5 \\
\hline Latvia & -1.8 & -4.9 & -11.0 & -1.6 & -5.8 & -10.8 & -18.6 & -18.2 \\
\hline Lithuania & -0.3 & -1.4 & -10.2 & -9.8 & 2.0 & -1.3 & -11.6 & -20.4 \\
\hline Luxembourg & -0.6 & -3.6 & -1.5 & $:$ & -0.9 & -5.0 & -5.4 & $:$ \\
\hline Malta & -0.3 & -1.1 & -1.3 & $:$ & 2.1 & -0.3 & -2.4 & $:$ \\
\hline Netherlands & -0.4 & -1.0 & -2.7 & -0.9 & 1.9 & -0.7 & -4.5 & -5.1 \\
\hline Norway & -0.9 & 0.4 & -0.8 & -1.3 & 1.2 & 0.5 & -0.7 & -2.5 \\
\hline Poland & 0.6 & -0.1 & 0.3 & 0.5 & 4.9 & 2.6 & 1.7 & 1.4 \\
\hline Portugal & -0.5 & -1.8 & -1.6 & 0.3 & 0.3 & -2.0 & -3.7 & -3.7 \\
\hline Romania & -0.1 & -2.8 & -4.6 & -1.2 & 9.2 & 2.9 & -6.2 & -8.8 \\
\hline Slovakia & 1.8 & 2.1 & -11.0 & 2.2 & 6.6 & 2.5 & -5.6 & -5.3 \\
\hline Slovenia & 0.7 & -4.1 & -6.4 & 0.7 & 3.7 & -0.9 & -8.9 & -9.0 \\
\hline Spain & -0.6 & -1.1 & -1.6 & -1.1 & 0.5 & -1.2 & -3.2 & -4.2 \\
\hline Sweden & -0.5 & -5.0 & -0.9 & 0.0 & 0.2 & -5.1 & -6.3 & -6.3 \\
\hline Switzerland & -0.4 & -0.6 & -0.9 & -0.3 & 1.3 & -0.2 & -1.6 & -2.1 \\
\hline United Kingdom & -0.7 & -1.8 & -2.4 & -0.7 & 0.5 & -1.8 & -4.9 & -5.5 \\
\hline United States & -0.7 & -1.4 & -1.6 & -0.3 & 0.0 & -1.9 & -3.3 & -3.9 \\
\hline
\end{tabular}

Source: Eurostat

http://epp.eurostat.ec.europa.eu/cache/ITY PUBLIC/2-02092009-BP/EN/2-02092009-BP$\underline{\text { EN.PDF }}$ 
Table 2. Turning Points Based on Output

\begin{tabular}{|c|c|c|c|c|}
\hline Change in Output & & & & \\
\hline & Peak Output & $\begin{array}{c}\text { Turning } \\
\text { Point }\end{array}$ & Decline & $\begin{array}{c}\text { latest obs } \\
2009 \text { Q }\end{array}$ \\
\hline Turkey & 148.2 & 2008Q1 & 20.2 & 1 \\
\hline Slovak Republic & 166.8 & 2008Q4 & 19.1 & 1 \\
\hline Ireland & 147.4 & 2007Q1 & 14.2 & 1 \\
\hline Mexico & 121.7 & $2008 \mathrm{Q} 2$ & 10.7 & 1 \\
\hline Japan & 112.6 & 2008Q1 & 9.5 & 1 \\
\hline Luxembourg & 134.9 & 2007Q4 & 8.6 & 1 \\
\hline Iceland & 139.9 & 2007Q3 & 8.0 & 1 \\
\hline Sweden & 122.9 & 2008Q1 & 7.8 & 2 \\
\hline Germany & 111.2 & 2008Q1 & 7.7 & 1 \\
\hline Finland & 126.3 & 2008Q1 & 7.6 & 1 \\
\hline Czech Republic & 141.6 & 2008Q3 & 7.2 & 1 \\
\hline Hungary & 132.1 & 2008Q1 & 7.2 & 1 \\
\hline UK & 121.3 & 2008Q2 & 6.6 & 2 \\
\hline Italy & 108.6 & 2008Q1 & 6.5 & 1 \\
\hline Denmark & 110.9 & 2007Q4 & 5.3 & 1 \\
\hline Netherlands & 117.3 & 2008Q1 & 4.9 & 1 \\
\hline USA & 119.5 & 2008Q2 & 4.7 & 2 \\
\hline Belgium & 116.4 & 2008Q3 & 4.4 & 2 \\
\hline Portugal & 108.6 & 2008Q2 & 4.2 & 1 \\
\hline Spain & 128.5 & 2008Q2 & 4.1 & 1 \\
\hline South Korea & 142.9 & 2008Q3 & 3.9 & 2 \\
\hline New Zealand & 127.8 & 2007Q4 & 3.8 & 1 \\
\hline France & 114.9 & 2008Q1 & 3.7 & 1 \\
\hline Austria & 118.3 & 2008Q3 & 3.5 & 1 \\
\hline Canada & 120.4 & 2007Q4 & 2.7 & 1 \\
\hline Greece & 138.3 & 2008Q4 & 1.6 & 1 \\
\hline Norway & 120.4 & 2008Q2 & 0.5 & 1 \\
\hline Australia & 128.4 & 2008Q3 & 0.3 & 1 \\
\hline Poland & 139.6 & 2009Q1 & 0 & 1 \\
\hline Euro Area & 115.6 & 2008Q1 & 5.6 & 1 \\
\hline European Union & 117.9 & 2008Q1 & 5.6 & 1 \\
\hline G7 & 116.4 & 2008Q2 & 5.4 & 1 \\
\hline OECD Total & 119.5 & 2008Q1 & 5.6 & 1 \\
\hline OECD Europe & 119.6 & 2008Q1 & 5.9 & 1 \\
\hline
\end{tabular}


Table 3: Turning Points Based on Employment

\begin{tabular}{|l|r|r|r|r|r|c|}
\hline & $\begin{array}{c}\text { Peak } \\
\text { Employment } \\
(000 \mathrm{~s})\end{array}$ & $\begin{array}{c}\text { Turning } \\
\text { Point }\end{array}$ & $\begin{array}{c}\text { Decline } \\
(000 \mathrm{~s})\end{array}$ & $\begin{array}{c}\text { Decline } \\
(\%)\end{array}$ & $\begin{array}{c}\text { latest } \\
\text { obs } \\
2009 \\
\text { Q }\end{array}$ & $\begin{array}{c}\text { Ratio of Fall in } \\
\text { Employment to } \\
\text { Increase in } \\
\text { Unemployment }\end{array}$ \\
\hline Ireland & 2,145 & $2008 \mathrm{Q} 1$ & 185 & $8.6 \%$ & 1 & $127.6 \%$ \\
\hline Spain & 20,532 & $2008 \mathrm{Q} 1$ & 1321 & $6.4 \%$ & 2 & $55.1 \%$ \\
\hline United States & 146,275 & $2007 \mathrm{Q} 4$ & 5684 & $3.9 \%$ & 2 & $75.1 \%$ \\
\hline Hungary & 3907 & $2007 \mathrm{Q} 2$ & 135 & $3.5 \%$ & 1 & $198.5 \%$ \\
\hline Sweden & 4,630 & $2008 \mathrm{Q} 3$ & 126 & $2.7 \%$ & 2 & $97.7 \%$ \\
\hline Japan & 64,230 & $2007 \mathrm{Q} 2$ & 1567 & $2.4 \%$ & 2 & $169.8 \%$ \\
\hline Slovakia & 2,460 & $2008 \mathrm{Q} 3$ & 58 & $2.4 \%$ & 1 & $28.4 \%$ \\
\hline Canada & 17,146 & $2008 \mathrm{Q} 4$ & 302 & $1.8 \%$ & 2 & $64.3 \%$ \\
\hline Portugal & 5,178 & $2008 \mathrm{Q} 2$ & 90 & $1.7 \%$ & 1 & $134.3 \%$ \\
\hline Turkey & 21,566 & $2008 \mathrm{Q} 2$ & 373 & $1.7 \%$ & 1 & $33.9 \%$ \\
\hline Denmark & 2,833 & $2008 \mathrm{Q} 2$ & 41 & $1.4 \%$ & 1 & $83.7 \%$ \\
\hline Italy & 23,191 & $2008 \mathrm{Q} 2$ & 273 & $1.2 \%$ & 1 & $81.7 \%$ \\
\hline Belgium & 4,465 & $2008 \mathrm{Q} 3$ & 47 & $1.1 \%$ & 1 & $71.2 \%$ \\
\hline Czech Republic & 5,010 & $2008 \mathrm{Q} 4$ & 57 & $1.1 \%$ & 1 & $78.1 \%$ \\
\hline Greece & 4,566 & $2008 \mathrm{Q} 4$ & 48 & $1.1 \%$ & 1 & $72.7 \%$ \\
\hline United Kingdom & 29,512 & $2008 \mathrm{Q} 2$ & 319 & $1.1 \%$ & 1 & $55.2 \%$ \\
\hline Austria & 4,099 & $2008 \mathrm{Q} 4$ & 40 & $1.0 \%$ & 1 & $571.4 \%$ \\
\hline Germany & 39,169 & $2008 \mathrm{Q} 4$ & 325 & $0.8 \%$ & 1 & $116.1 \%$ \\
\hline Norway & 2,515 & $2008 \mathrm{Q} 4$ & 18 & $0.7 \%$ & 1 & $85.7 \%$ \\
\hline South Korea & 23,612 & $2008 \mathrm{Q} 3$ & 176 & $0.7 \%$ & 2 & $451.3 \%$ \\
\hline France & 25,942 & $2008 \mathrm{Q} 4$ & 112 & $0.4 \%$ & 1 & $24.9 \%$ \\
\hline Poland & 15,942 & $2008 \mathrm{Q} 4$ & 45 & $0.3 \%$ & 1 & $18.6 \%$ \\
\hline Australia & 10,804 & $2009 \mathrm{Q} 1$ & 20 & $0.2 \%$ & 2 & $10.3 \%$ \\
\hline Netherlands & 7,443 & $2009 \mathrm{Q} 1$ & 0 & $0.0 \%$ & 1 & $0.0 \%$ \\
\hline & & & & & & \\
\hline
\end{tabular}

Source: OECD Main Economic Indicators 
Table 4. Turning Points Based on Unemployment

\begin{tabular}{|l|c|c|c|c|c|}
\hline Country & $\begin{array}{c}\text { Minimum } \\
\text { Unemploy } \\
\text { ment } \\
\text { Rate (\%) }\end{array}$ & $\begin{array}{c}\text { Turning } \\
\text { Point }\end{array}$ & $\begin{array}{c}\text { Increase in } \\
\text { Rnempeyment } \\
\text { Rat) }\end{array}$ & $\begin{array}{c}\text { Increase in } \\
\text { Unemployment } \\
(000 \text { s) }\end{array}$ & $\begin{array}{c}\text { Latest } \\
\text { obs 2009 }\end{array}$ \\
\hline Spain & 7.9 & May-07 & 10.2 & 2399 & Jun \\
\hline Ireland & 4.2 & Aug-07 & 8.0 & 145 & Jun \\
\hline United States & 4.4 & Mar-07 & 5.0 & 7567 & Jul \\
\hline Turkey & 8.1 & Dec-06 & 4.4 & 1099 & Mar \\
\hline Hungary & 6.1 & Mar-08 & 4.2 & 68 & Jun \\
\hline Sweden & 5.6 & Jun-08 & 3.4 & 129 & Jun \\
\hline Denmark & 3.1 & Jun-08 & 3.1 & 49 & Jun \\
\hline UK & 4.6 & Mar-08 & 2.9 & 578 & Apr \\
\hline Canada & 5.8 & Jan-08 & 2.8 & 470 & Jul \\
\hline OECD - Total & 5.6 & Jun-07 & 2.7 & 15,121 & Jun \\
\hline Slovak Republic & 9.0 & Oct-08 & 2.7 & 39 & Jun \\
\hline Luxembourg & 4.0 & Sep-07 & 2.4 & 4 & Jun \\
\hline Mexico & 3.2 & May-08 & 2.4 & 697 & Jun \\
\hline Portugal & 6.9 & May-08 & 2.4 & 67 & Jun \\
\hline Finland & 6.2 & Apr-08 & 2.3 & 57 & Jun \\
\hline OECD - Europe & 6.8 & Apr-08 & 2.1 & 5,483 & Jun \\
\hline Czech Republic & 4.3 & Sep-08 & 2.0 & 73 & Jun \\
\hline Australia & 3.9 & Feb-08 & 1.9 & 195 & Jul \\
\hline France & 7.6 & Apr-08 & 1.8 & 450 & Jun \\
\hline Japan & 3.6 & Jul-07 & 1.8 & 923 & Jun \\
\hline Belgium & 6.6 & May-08 & 1.5 & 66 & Jun \\
\hline Italy & 5.9 & Jun-07 & 1.5 & 334 & Mar \\
\hline Poland & 6.8 & Oct-08 & 1.4 & 242 & Jun \\
\hline Greece & 7.5 & Jun-08 & 1.2 & 66 & Mar \\
\hline South Korea & 3.0 & Jan-08 & 1.0 & 204 & Jun \\
\hline Austria & 3.6 & Jun-08 & 0.8 & 7 & Jun \\
\hline Norway & 2.3 & Mar-08 & 0.8 & 21 & Apr \\
\hline Germany & 7.1 & Dec-08 & 0.6 & 280 & Jun \\
\hline Netherlands & 2.7 & Nov-08 & 0.6 & 32 & Jun \\
\hline
\end{tabular}

Source: OECD Main Economic Indicators 
Table 5. House Price Inflation 2009

\begin{tabular}{|l|c|l|c|}
\hline Country & $\begin{array}{l}\text { Year on Year } \\
\text { Change to 2009 Q1 }\end{array}$ & Country & $\begin{array}{l}\text { Year on Year } \\
\text { Change to 2009 Q1 }\end{array}$ \\
\hline Israel & $10.9 \%$ & Canada & $-2.4 \%$ \\
\hline Czech Republic & $9.9 \%$ & Luxembourg & $-2.4 \%$ \\
\hline Switzerland & $5.6 \%$ & Slovenia & $-3.1 \%$ \\
\hline India & $5.1 \%$ & China & $-3.9 \%$ \\
\hline Indonesia & $4.6 \%$ & New Zealand & $-4.0 \%$ \\
\hline Austria & $4.1 \%$ & Croatia & $-4.5 \%$ \\
\hline Russia & $3.6 \%$ & Malta & $-5.6 \%$ \\
\hline Bulgaria & $3.3 \%$ & France & $-5.7 \%$ \\
\hline Belgium & $2.7 \%$ & Portugal & $-5.9 \%$ \\
\hline Hungary & $2.5 \%$ & Australia & $-6.7 \%$ \\
\hline Netherlands & $1.0 \%$ & Spain & $-6.8 \%$ \\
\hline Lithuania & $0.8 \%$ & Norway & $-9.4 \%$ \\
\hline Slovakia & $0.3 \%$ & Ireland & $-10.0 \%$ \\
\hline Italy & $0.1 \%$ & Denmark & $-11.6 \%$ \\
\hline South Africa & $-0.3 \%$ & Poland & $-13.0 \%$ \\
\hline Sweden & $-0.6 \%$ & Hong Kong & $-15.7 \%$ \\
\hline Finland & $-0.7 \%$ & Estonia & $-16.2 \%$ \\
\hline Germany & $-1.5 \%$ & UK & $-16.5 \%$ \\
\hline Greece & $-1.5 \%$ & USA & $-16.9 \%$ \\
\hline Ukraine & $-2.3 \%$ & Latvia & $-36.0 \%$ \\
\hline
\end{tabular}

Source: Knight, Frank and Rutley

[Accessed at: http://www.knightfrank.co.uk/news/Knight-Frank-Global-House-Price-IndexQ1-2009-030.aspX 
Table 6. Co-movement of Output and Employment

\begin{tabular}{|c|c|c|c|c|}
\hline & & \multicolumn{3}{|c|}{ Fall in Employment } \\
\hline & & $<2 \%$ & $>2 \%$ and $<4 \%$ & $>4 \%$ \\
\hline \multirow{3}{*}{$\begin{array}{l}\text { Fall in } \\
\text { Output }\end{array}$} & $<2 \%$ & $\begin{array}{l}\text { Australia } \\
\text { Greece } \\
\text { Norway } \\
\text { Poland }\end{array}$ & & \\
\hline & $>2 \%$ and $<4 \%$ & $\begin{array}{l}\text { Austria } \\
\text { Canada } \\
\text { France } \\
\text { South Korea }\end{array}$ & & Spain \\
\hline & $>4 \%$ & $\begin{array}{l}\text { Belgium } \\
\text { Czech Republic } \\
\text { Denmark } \\
\text { Germany } \\
\text { Italy } \\
\text { Netherlands } \\
\text { Portugal } \\
\text { Turkey } \\
\text { United Kingdom }\end{array}$ & $\begin{array}{l}\text { Hungary } \\
\text { Japan } \\
\text { Sweden } \\
\text { United States }\end{array}$ & Ireland \\
\hline
\end{tabular}

Source: OECD Main Economic Indicators 
Table 7. Youth unemployment rates (age under 25) - \%

\begin{tabular}{|l|c|c|c|c|c|c|}
\cline { 2 - 7 } \multicolumn{1}{c|}{} & Age<25 & Age<25 & Age<25 & Age<25 & All & $<$ 25/all \\
\cline { 2 - 7 } \multicolumn{1}{c|}{} & $\begin{array}{c}\text { July } \\
\mathbf{2 0 0 8}\end{array}$ & $\begin{array}{c}\text { May } \\
\mathbf{2 0 0 9}\end{array}$ & $\begin{array}{c}\text { June } \\
\mathbf{2 0 0 9}\end{array}$ & $\begin{array}{c}\text { July } \\
\mathbf{2 0 0 9}\end{array}$ & $\begin{array}{c}\text { July } \\
\mathbf{2 0 0 9}\end{array}$ & $\begin{array}{c}\text { July } \\
\mathbf{2 0 0 9}\end{array}$ \\
\hline EA16 & 15.4 & 19.4 & 19.6 & 19.7 & 9.5 & 2.1 \\
\hline EU27 & 15.4 & 19.5 & 19.7 & 19.8 & 9.0 & 2.2 \\
\hline Austria & 7.3 & 8.3 & 8.3 & 8.2 & 4.4 & 1.9 \\
\hline Belgium & 19.9 & 21.9 & 22.1 & 21.6 & 8.0 & 2.7 \\
\hline Bulgaria & 12.0 & 14.9 & 15.3 & 15.9 & 7.0 & 2.3 \\
\hline Cyprus & 9.0 & 12.6 & 12.6 & $:$ & 5.5 & 2.3 \\
\hline Czech Rep. & 9.8 & 13.4 & 13.6 & 13.7 & 6.4 & 2.1 \\
\hline Denmark & 7.9 & 11.1 & 11.4 & 11.2 & 5.9 & 1.9 \\
\hline Finland & 16.5 & 21.5 & 22.1 & 22.6 & 8.7 & 2.6 \\
\hline France & 19.3 & 23.8 & 24.0 & 24.2 & 9.8 & 2.5 \\
\hline Germany & 9.6 & 11.0 & 11.1 & 11.2 & 7.7 & 1.5 \\
\hline Hungary & 19.9 & 27.0 & 26.6 & 25.8 & 10.3 & 2.5 \\
\hline Ireland & 12.4 & 24.9 & 25.3 & 25.5 & 12.5 & 2.0 \\
\hline Latvia & 13.0 & 29.2 & 29.2 & $:$ & 17.4 & 1.7 \\
\hline Lithuania & 14.9 & 30.9 & 30.9 & $:$ & 16.7 & 1.9 \\
\hline Luxembourg & 17.0 & 20.0 & 20.3 & 20.5 & 6.4 & 3.2 \\
\hline Malta & 12.2 & 14.9 & 15.1 & 15.1 & 7.3 & 2.1 \\
\hline Netherlands & 5.3 & 6.3 & 6.5 & 6.6 & 3.4 & 1.9 \\
\hline Poland & 16.6 & 19.6 & 19.8 & 19.8 & 8.2 & 2.4 \\
\hline Portugal & 16.7 & 19.8 & 19.5 & 18.9 & 9.2 & 2.1 \\
\hline Slovak Rep. & 19.0 & 25.0 & 25.5 & 26 & 12.0 & 2.2 \\
\hline Slovenia & 10.2 & 16.0 & 16.0 & $:$ & 6.0 & 2.7 \\
\hline Spain & 25.0 & 37.0 & 37.5 & 38.4 & 18.5 & 2.1 \\
\hline Sweden & 17.7 & 26.2 & 26.8 & 27.3 & 9.2 & 3.0 \\
\hline UK & 15.0 & 19.2 & $:$ & $:$ & 7.8 & 2.5 \\
\hline USA & 13.5 & 17.3 & 17.8 & 17.8 & 9.4 & 1.9 \\
\hline
\end{tabular}

Source: Eurostat. 1 September 2009

http://epp.eurostat.ec.europa.eu/cache/ITY PUBLIC/3-01092009-AP/EN/3-01092009-APEN.PDF 
Table 8. Size of youth cohort in 2008 where the number of 20 year olds $=100$

\begin{tabular}{|l|r|r|r|r|r|}
\hline & 5 yrs & 10 yrs & \multicolumn{1}{|c|}{15 yrs } & \multicolumn{1}{|c|}{25 yrs } & \# Age 20 \\
\hline Euro area & 87.6 & 88.3 & 93.3 & 110.8 & $3,814,153$ \\
\hline Armenia & 50.0 & 70.2 & 93.7 & 91.7 & 63,333 \\
\hline Australia & 89.3 & 92.1 & 96.2 & 104.4 & 296,556 \\
\hline Austria & 81.5 & 88.2 & 99.4 & 111.7 & 100,537 \\
\hline Belarus & 53.9 & 54.1 & 77.0 & 97.4 & 162,934 \\
\hline Belgium & 90.7 & 95.0 & 102.4 & 105.3 & 127,376 \\
\hline Bulgaria & 64.5 & 57.4 & 80.0 & 104.7 & 103,028 \\
\hline Croatia & 73.0 & 92.7 & 88.4 & 112.2 & 55,644 \\
\hline Cyprus & 68.3 & 81.8 & 99.4 & 114.5 & 11,757 \\
\hline Czech Republic & 69.5 & 67.3 & 90.7 & 109.4 & 134,600 \\
\hline Denmark & 104.9 & 111.6 & 114.3 & 98.3 & 61,689 \\
\hline Estonia & 59.1 & 55.2 & 76.4 & 93.0 & 21,838 \\
\hline Finland & 90.8 & 96.8 & 109.2 & 111.6 & 61,957 \\
\hline France & 97.4 & 93.0 & 96.2 & 101.9 & 817,614 \\
\hline Georgia & 62.8 & 73.6 & 96.8 & 94.1 & 72,102 \\
\hline Germany & 73.6 & 83.1 & 85.8 & 102.7 & 982,931 \\
\hline Greece & 87.4 & 88.0 & 94.8 & 130.2 & 119,656 \\
\hline Hungary & 76.8 & 78.5 & 95.6 & 108.5 & 125,807 \\
\hline Iceland & 93.6 & 98.2 & 106.9 & 109.7 & 4,399 \\
\hline Ireland & 104.1 & 98.2 & 95.1 & 136.5 & 59,194 \\
\hline Italy & 93.8 & 93.0 & 100.2 & 115.1 & 591,715 \\
\hline Latvia & 52.8 & 48.6 & 79.6 & 91.8 & 37,681 \\
\hline Lithuania & 53.3 & 65.6 & 93.6 & 87.3 & 55,381 \\
\hline Luxembourg & 104.3 & 109.7 & 106.5 & 115.3 & 5,504 \\
\hline Macedonia & 68.8 & 77.7 & 93.5 & 100.0 & 33,263 \\
\hline Moldova & 49.3 & 58.4 & 80.2 & 82.3 & 73,876 \\
\hline Montenegro & 80.4 & 82.1 & 90.7 & 100.9 & 10,053 \\
\hline Netherlands & 101.2 & 97.9 & 101.3 & 97.3 & 198,534 \\
\hline Norway & 98.5 & 107.1 & 108.8 & 100.2 & 58,239 \\
\hline Poland & 60.7 & 70.2 & 87.0 & 113.6 & 579,666 \\
\hline Portugal & 94.3 & 88.4 & 93.8 & 124.6 & 120,091 \\
\hline Romania & 58.5 & 62.2 & 71.1 & 89.0 & 352,397 \\
\hline Russian Federation & 53.7 & 49.9 & 65.4 & 96.6 & $2,556,769$ \\
\hline Serbia & 81.6 & 78.0 & 87.4 & 106.2 & 95,973 \\
\hline Slovakia & 61.1 & 70.1 & 89.4 & 109.8 & 82,551 \\
\hline Slovenia & 67.7 & 70.1 & 76.8 & 111.0 & 26,541 \\
\hline Spain & 88.9 & 81.6 & 86.8 & 131.5 & 502,550 \\
\hline Sweden & 86.2 & 82.4 & 110.5 & 94.9 & 115,360 \\
\hline Switzerland & 84.1 & 92.3 & 102.2 & 106.9 & 88,726 \\
\hline Ukraine & 57.4 & 76.6 & 97.8 & 744,442 \\
\hline United Kingdom & 94.2 & 102.3 & 102.8 & $4,168,920$ \\
\hline USA & & & & \\
\hline
\end{tabular}


Table 9. Unemployment Rate by Age and Educational Attainment 2008 Quarter 3

\begin{tabular}{|l|c|c|c|c|c|c|c|c|}
\hline & \multicolumn{2}{|c|}{ Total } & \multicolumn{2}{c|}{ ISCED -2} & \multicolumn{2}{c|}{ ISCED 3-4 } & \multicolumn{2}{c|}{ ISCED 5-6 } \\
\hline & $15-24$ & $25-64$ & $15-24$ & $25-64$ & $15-24$ & $25-64$ & $15-24$ & $25-64$ \\
\hline European Union (27 countries) & 15.6 & 5.7 & 21.2 & 9.4 & 12.7 & 5.2 & 13.3 & 3.5 \\
\hline Euro area & 15.3 & 6.2 & 19.7 & 9.8 & 12.4 & 5.5 & 12.5 & 3.9 \\
\hline Austria & 8.2 & 3.0 & 12.0 & 6.0 & 5.9 & 2.7 & $:$ & 1.9 \\
\hline Belgium & 22.7 & 6.2 & 32.7 & 11.6 & 18.3 & 5.7 & 21.5 & 3.5 \\
\hline Bulgaria & 11.4 & 4.6 & 25.6 & 12.1 & 8.5 & 3.6 & $:$ & 1.9 \\
\hline Croatia & 20.2 & 5.6 & $:$ & 7.3 & 18.7 & 5.7 & $:$ & 3.8 \\
\hline Cyprus & 8.4 & 3.2 & 7.2 & 4.1 & 6.7 & 2.8 & 12.1 & 2.9 \\
\hline Czech Republic & 10.3 & 3.8 & 33.4 & 16.4 & 7.5 & 3.1 & 11.4 & 1.9 \\
\hline Denmark & 8.7 & 2.4 & 8.9 & 2.9 & 7.9 & 2.2 & $:$ & 2.2 \\
\hline Estonia & 14.7 & 5.0 & $:$ & 10.8 & 13.1 & 5.5 & $:$ & 2.9 \\
\hline Finland & 11.2 & 4.8 & 17.9 & 7.7 & 7.9 & 5.0 & $:$ & 3.4 \\
\hline France & 17.7 & 5.9 & 29.0 & 9.3 & 16.3 & 5.4 & 9.3 & 3.9 \\
\hline Germany & 11.0 & 6.6 & 15.2 & 15.6 & 7.7 & 6.5 & $:$ & 3.1 \\
\hline Greece & 21.3 & 6.2 & 17.8 & 6.2 & 22.2 & 6.6 & 25.7 & 5.7 \\
\hline Hungary & 20.8 & 6.7 & 32.1 & 16.3 & 18.1 & 6.1 & 19.2 & 2.4 \\
\hline Ireland & 15.1 & 5.2 & 27.2 & 8.7 & 13.0 & 4.8 & 9.7 & 3.3 \\
\hline Italy & 19.5 & 5.1 & 21.3 & 6.7 & 18.7 & 4.0 & 15.2 & 4.3 \\
\hline Latvia & 12.2 & 6.7 & 18.4 & 12.1 & 10.2 & 7.1 & $:$ & 3.7 \\
\hline Lithuania & 15.0 & 4.9 & 27.0 & 8.3 & 11.2 & 6.1 & 16.8 & 2.4 \\
\hline Luxembourg & 23.9 & 3.6 & 22.6 & 4.7 & 24.5 & 4.1 & $:$ & 2.1 \\
\hline Netherlands & 4.9 & 1.9 & 6.6 & 2.8 & 3.5 & 1.8 & $:$ & 1.4 \\
\hline Norway & 7.2 & 1.7 & 9.8 & 3.7 & 4.3 & 1.2 & $:$ & 1.4 \\
\hline Poland & 16.1 & 5.6 & 16.5 & 10.2 & 15.6 & 5.8 & 20.0 & 3.2 \\
\hline Portugal & 17.1 & 7.2 & 16.4 & 7.5 & 13.0 & 6.6 & 34.3 & 6.8 \\
\hline Romania & 19.2 & 4.1 & 20.1 & 5.5 & 18.0 & 4.2 & 25.6 & 1.7 \\
\hline Slovakia & 19.4 & 7.8 & 52.6 & 30.3 & 15.3 & 6.9 & 24.9 & 3.0 \\
\hline Slovenia & 9.1 & 3.5 & 10.0 & 5.9 & 8.9 & 3.2 & $:$ & 3.0 \\
\hline Spain & 24.2 & 9.8 & 28.9 & 13.6 & 19.1 & 8.4 & 17.9 & 5.9 \\
\hline Sweden & 16.2 & 4.0 & 24.6 & 6.9 & 9.4 & 3.8 & $:$ & 3.3 \\
\hline United Kingdom & 16.7 & 4.0 & 30.3 & 6.6 & 12.3 & 4.2 & 12.4 & 2.4 \\
\hline
\end{tabular}


Notes: International Standard Classification of Education (ISCED) levels are as follows.

ISCED 0: PRE-PRIMARY EDUCATION. Pre-primary education (ISCED 0) is defined as the initial stage of organised instruction, designed primarily to introduce very young children to a school-type environment, that is, to provide a bridge between home and a school-based atmosphere. ISCED 0 does not include early childhood care services as they are not considered as 'organised instruction'.

ISCED 1: PRIMARY EDUCATION. This level is compulsory in all countries and generally begins between five and seven years of age and lasts from four to six years.

ISCED 2: LOWER-SECONDARY EDUCATION. - This level continues the basic programmes of the primary level, although teaching is typically more subject-focused. Usually, the end of this level coincides with the end of compulsory education.

ISCED 3: UPPER-SECONDARY EDUCATION. This level generally begins at the end of compulsory education. The entrance age is typically 15 or 16 years. Entrance qualifications (end of compulsory education) and other minimum entry requirements are usually needed. Instruction is often more subject-oriented than at ISCED level 2. The typical duration of ISCED level 3 varies from two to five years.

ISCED 4: POST-SECONDARY NON-TERTIARY LEVEL OF EDUCATION. ISCED 4 straddles the boundary between upper-secondary and post-secondary education from an international point of view. Although their content may not be significantly more advanced than uppersecondary programmes, they serve to broaden the knowledge of participants who have already gained an upper-secondary qualification.

ISCED 5: TERTIARY EDUCATION. Post-secondary education is either: 1) Type A - largely theory-based with a minimum cumulative theoretical duration (at tertiary level) of three years' full-time equivalent, although it typically lasts four or more years; or 2) Type B - practical, technical or occupational skills-based with a minimum duration of two years full-time equivalent at the tertiary level.

ISCED 6: SECOND STAGE OF TERTIARY EDUCATION. This level is reserved for tertiary programmes that lead directly to the award of an advanced research qualification. The theoretical duration of these programmes is 3 years full-time in most countries (for a cumulative total of at least 7 years FTE at the tertiary level), although the actual enrolment time is typically longer. The programmes are devoted to advanced study and original research. For successful completion, requires - The submission of a thesis or dissertation of publishable quality that is the product of original research and represents a significant contribution to knowledge.

- Is not solely based on course-work.

- Prepares recipients for faculty posts in institutions offering ISCED 5A programmes, as well as research posts in government and industry

Source: OECD 
Table 10. Views on the state of the labour market in the United States

\begin{tabular}{|c|c|c|c|c|}
\hline Month & Less & Same & More & DK \\
\hline Jan-07 & 12 & 60 & 27 & 1 \\
\hline Feb-07 & 8 & 58 & 33 & \\
\hline Mar-07 & 10 & 57 & 33 & \\
\hline Apr-07 & 9 & 53 & 38 & \\
\hline Мay-07 & 10 & 59 & 30 & \\
\hline Jun-07 & 12 & 51 & 37 & \\
\hline Jul-07 & 10 & 56 & 33 & \\
\hline Aug-07 & 8 & 52 & 39 & \\
\hline Sep-07 & 9 & 54 & 36 & \\
\hline Oct-07 & 8 & 54 & 38 & \\
\hline Nov-07 & 11 & 50 & 39 & \\
\hline Dec-07 & 8 & 45 & 47 & \\
\hline Jan-08 & 6 & 46 & 47 & ( \\
\hline Feb-08 & 9 & 41 & 50 & \\
\hline Mar-08 & 7 & 38 & 55 & \\
\hline Apr-08 & 5 & 36 & 59 & \\
\hline Мay-08 & 3 & 41 & 56 & \\
\hline Jun-08 & 5 & 31 & 64 & 0 \\
\hline Jul-08 & 7 & 32 & 61 & \\
\hline Aug-08 & 5 & 40 & 55 & \\
\hline Sep-08 & 9 & 41 & 50 & \\
\hline Oct-08 & 6 & 31 & 62 & \\
\hline Nov-08 & 7 & 24 & 69 & \\
\hline Dec-08 & 7 & 24 & 69 & \\
\hline Jan-09 & 12 & 21 & 66 & 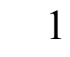 \\
\hline Feb-09 & 10 & 20 & 69 & 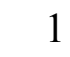 \\
\hline \multicolumn{5}{|l|}{ Average } \\
\hline \multicolumn{5}{|l|}{ 2000(1)- } \\
\hline $2009(1)$ & 14.0 & 46.5 & 38.5 & \\
\hline
\end{tabular}

Question. How about people out of work during the coming 12 months--do you think that there will be more unemployment than now, about the same, or less? 
b) Conference Board - jobs are currently plentiful (\%)

Plentiful Not so plentiful Hard to find US unemployment

\begin{tabular}{|c|c|c|c|c|}
\hline Jan-07 & 29.6 & 50.7 & 19.7 & 4.6 \\
\hline Feb-07 & 27.8 & 54.3 & 17.9 & 4.5 \\
\hline Mar-07 & 30.3 & 50.8 & 18.9 & 4.4 \\
\hline Apr-07 & 29.0 & 50.7 & 20.3 & 4.5 \\
\hline Мay-07 & 29.1 & 51.2 & 19.7 & 4.5 \\
\hline Jun-07 & 27.6 & 51.9 & 20.5 & 4.6 \\
\hline Jul-07 & 30.0 & 51.3 & 18.7 & 4.7 \\
\hline Aug-07 & 27.5 & 52.8 & 19.7 & 4.7 \\
\hline Sep-07 & 25.6 & 52.0 & 22.4 & 4.7 \\
\hline Oct-07 & 24.1 & 53.1 & 22.8 & 4.8 \\
\hline Nov-07 & 23.3 & 55.3 & 21.4 & 4.7 \\
\hline Dec-07 & 23.6 & 53.7 & 22.7 & 4.9 \\
\hline Jan-08 & 23.8 & 55.6 & 20.6 & 4.9 \\
\hline Feb-08 & 21.5 & 55.1 & 23.4 & 4.8 \\
\hline Mar-08 & 19.2 & 56.3 & 24.5 & 5.1 \\
\hline Apr-08 & 17.1 & 55.0 & 27.9 & 5.0 \\
\hline May-08 & 16.1 & 55.6 & 28.3 & 5.5 \\
\hline Jun-08 & 14.1 & 56.2 & 29.7 & 5.6 \\
\hline Jul-08 & 13.6 & 56.2 & 30.2 & 5.8 \\
\hline Aug-08 & 13.5 & 54.8 & 31.7 & 6.2 \\
\hline Sep-08 & 12.6 & 55.2 & 32.2 & 6.2 \\
\hline Oct-08 & 9.0 & 54.4 & 36.6 & 6.6 \\
\hline Nov-08 & 8.7 & 54.2 & 37.1 & 6.8 \\
\hline Dec-08 & 6.5 & 52.0 & 41.5 & 7.2 \\
\hline Jan-09 & 7.1 & 51.8 & 41.1 & 7.6 \\
\hline Feb-09 & 4.6 & 48.5 & 46.9 & 8.1 \\
\hline Mar-09 & 4.7 & 46.5 & 48.8 & 8.5 \\
\hline Apr-09 & 4.9 & 48.5 & 46.6 & 8.9 \\
\hline Мay-09 & 5.8 & 50.3 & 43.9 & 9.4 \\
\hline Jun-09 & 4.5 & 50.7 & 44.8 & 9.5 \\
\hline Jul-09 & 3.7 & 47.8 & 48.5 & 9.4 \\
\hline Aug-09 & 4.2 & 50.7 & 45.1 & 9.7 \\
\hline Average & 21.5 & 49.8 & 28.7 & \\
\hline
\end{tabular}


Table 11. The 'fear of unemployment' balances by EU country, January 2008-August 2009

\begin{tabular}{|c|c|c|c|c|c|c|c|c|c|c|c|c|c|c|c|c|}
\hline Country & (1) & (2) & (3) & (4) & (5) & (6) & (7) & $(8)$ & (9) & (10) & (11) & (12) & (13) & (14) & (15) & (16) \\
\hline Jan-08 & 13 & 10 & 4 & 3 & -2 & 47 & 44 & 25 & 7 & 21 & -12 & 1 & 50 & -2 & -6 & 28 \\
\hline Feb-08 & 16 & 14 & 3 & 6 & 3 & 53 & 41 & 28 & 11 & 23 & -5 & 2 & 48 & 7 & 4 & 30 \\
\hline Mar-08 & 16 & 14 & -1 & 4 & 4 & 50 & 45 & 24 & 15 & 24 & -5 & 1 & 45 & -3 & 3 & 29 \\
\hline Apr-08 & 15 & 10 & 5 & 13 & -8 & 59 & 44 & 31 & 10 & 21 & -2 & -1 & 46 & -5 & 8 & 35 \\
\hline May-08 & 14 & 10 & 9 & 11 & -6 & & 45 & 39 & 12 & 16 & -4 & 5 & 49 & -4 & 13 & 31 \\
\hline Jun-08 & 16 & 11 & 7 & 16 & -5 & & 35 & 44 & 10 & 15 & 0 & 8 & 50 & -5 & 20 & 38 \\
\hline Jul-08 & 24 & 19 & 16 & 23 & 1 & & 52 & 52 & 18 & 26 & 0 & 11 & 54 & 4 & 24 & 48 \\
\hline Aug-08 & 28 & 24 & 18 & 17 & 15 & & 50 & 46 & 26 & 26 & 6 & 19 & 44 & 3 & 30 & 50 \\
\hline Sep-08 & 30 & 25 & 20 & 21 & 13 & & 47 & 56 & 29 & 27 & 10 & 18 & 38 & 8 & 32 & 52 \\
\hline Oct-08 & 42 & 38 & 44 & 37 & 16 & & 59 & 63 & 56 & 33 & 30 & 31 & 53 & 26 & 56 & 60 \\
\hline Nov-08 & 52 & 49 & 63 & 41 & 31 & & 63 & 67 & 62 & 42 & 52 & 50 & 64 & 44 & 62 & 66 \\
\hline Dec-08 & 61 & 59 & 70 & 46 & 48 & & 73 & 71 & 68 & 52 & 68 & 57 & 66 & 52 & 64 & 71 \\
\hline Jan-09 & 62 & 59 & 67 & 46 & 54 & & 59 & 67 & 67 & 46 & 69 & 59 & 77 & 47 & 59 & 75 \\
\hline Feb-09 & 65 & 64 & 76 & 51 & 64 & & 74 & 68 & 68 & 51 & 77 & 60 & 86 & 50 & 55 & 68 \\
\hline Mar-09 & 67 & 69 & 72 & 46 & 72 & & 73 & 59 & 74 & 59 & 81 & 64 & 77 & 46 & 58 & 65 \\
\hline Apr-09 & 61 & 63 & 70 & 32 & 71 & & 70 & 51 & 69 & 45 & 74 & 65 & 73 & 42 & 64 & 59 \\
\hline May-09 & 56 & 58 & 67 & 31 & 70 & 58 & 68 & 35 & 65 & 40 & 61 & 60 & 72 & 33 & 45 & 57 \\
\hline Jun-09 & 54 & 55 & 65 & 34 & 67 & 49 & 65 & 31 & 61 & 38 & 68 & 53 & 66 & 30 & 37 & 56 \\
\hline Jul-09 & 52 & 53 & 63 & 21 & 63 & 50 & 66 & 29 & 61 & 34 & 73 & 55 & 55 & 29 & 33 & 55 \\
\hline Aug-09 & 52 & 53 & 52 & 28 & 62 & 45 & 62 & 32 & & 36 & 63 & 46 & 53 & 32 & 21 & 53 \\
\hline
\end{tabular}




$\begin{array}{lrrrrrrrrrrrr}\text { Country } & (17) & (18) & (19) & (20) & (21) & (22) & (23) & (24) & (25) & (26) & (27) & (28) \\ \text { Jan-08 } & 7 & 2 & 8 & -14 & 37 & 4 & -23 & 19 & 47 & -4 & -12 & 18 \\ \text { Feb-08 } & 11 & -2 & 11 & -9 & 36 & 8 & -21 & 22 & 46 & -3 & -17 & 20 \\ \text { Mar-08 } & 7 & -2 & 15 & -6 & 35 & 11 & -18 & 20 & 49 & -13 & -13 & 14 \\ \text { Apr-08 } & 10 & 2 & 5 & -10 & 36 & 22 & -14 & 18 & 48 & -11 & -17 & 13 \\ \text { May-08 } & 4 & 1 & 12 & -8 & 29 & 22 & -3 & 18 & 47 & 0 & -17 & 11 \\ \text { Jun-08 } & 10 & 1 & 7 & -15 & 33 & 26 & 4 & 16 & 46 & 2 & -9 & 14 \\ \text { Jul-08 } & 9 & 5 & 13 & -10 & 33 & 28 & 12 & 22 & 44 & 5 & -10 & 13 \\ \text { Aug-08 } & 6 & 14 & 15 & -9 & 33 & 35 & 24 & 22 & 42 & 7 & -8 & 12 \\ \text { Sep-08 } & 3 & 11 & 11 & -6 & 30 & 40 & 24 & 25 & 44 & 3 & -6 & 15 \\ \text { Oct-08 } & 14 & 37 & 17 & 0 & 38 & 51 & 40 & 44 & 64 & 16 & 2 & 14 \\ \text { Nov-08 } & 39 & 45 & 53 & 49 & 47 & 62 & 53 & 54 & 73 & 30 & 13 & 48 \\ \text { Dec-08 } & 56 & 58 & 61 & 52 & 55 & 75 & 71 & 66 & 81 & 24 & 24 & 60 \\ \text { Jan-09 } & 52 & 65 & 73 & 54 & 53 & 79 & 78 & 66 & 82 & 22 & 34 & 67 \\ \text { Feb-09 } & 56 & 65 & 65 & 76 & 61 & 80 & 82 & 70 & 84 & 41 & 57 & 70 \\ \text { Mar-09 } & 58 & 49 & 67 & 77 & 65 & 75 & 82 & 70 & 80 & 34 & 59 & 74 \\ \text { Apr-09 } & 63 & 49 & 71 & 63 & 58 & 58 & 77 & 75 & 81 & 33 & 45 & 71 \\ \text { May-09 } & 56 & 43 & 56 & 55 & 53 & 49 & 75 & 66 & 75 & 31 & 40 & 71 \\ \text { Jun-09 } & 55 & 39 & 46 & 51 & 43 & 58 & 67 & 64 & 70 & 27 & 29 & 64 \\ \text { Jul-09 } & 53 & 43 & 49 & 46 & 50 & 69 & 66 & 57 & 70 & 30 & 32 & 70 \\ \text { Aug-09 } & & 46 & 46 & 48 & 55 & 73 & 71 & 53 & 67 & & 30 & 72\end{array}$

Notes. Countries are as follows

1 European Union

2. Euro area

3. Belgium

4. Denmark

5. Germany

6. Ireland

7. Greece

8. Spain

9. France

10. Italy
11. Netherlands

12. Austria

13. Portugal

14. Finland

15. Sweden

16. United Kingdom

17. Bulgaria

18. Czech Republic

19. Slovenia

20. Slovak Republic
21. Cyprus

22. Latvia

23. Lithuania

24. Luxembourg

25. Hungary

26. Malta

27. Poland

28. Romania

Question. How do you expect the number of people unemployed in this country to change over the next 12 months? The number will...+ + increase sharply; + increase slightly; = remain the same; - fall slightly; - - fall sharply.

Balances are the difference between positive and negative answering options, measured as percentage points of total answers. If P denotes 'increase slightly', while PP denotes the percentage of respondents having chosen the option "increase sharply", M denotes 'fall slightly", MM the percentage of respondents having chosen the option "fall sharply"and $\mathrm{N}$ is the percentage of respondents without any opinion (so that $\mathrm{PP}+\mathrm{P}+\mathrm{E}+\mathrm{M}+\mathrm{MM}+\mathrm{N}=100$ ), then the balance is calculated as $\mathrm{B}=(\mathrm{PP}+1 / 2 \mathrm{P})-(1 / 2 \mathrm{M}+\mathrm{MM})$ 
Appendix Table 1. Unemployment rates, January 2008-July 2009 (\%)

$\begin{array}{lcccccccccccccccc} & (1) & (2) & (3) & (4) & (5) & (6) & (7) & (8) & (9) & (10) & (11) & (12) & (13) & (14) & (15) & (16) \\ \text { Jan-2008 } & 6.8 & 7.3 & 7.1 & 3.2 & 7.8 & 4.6 & 7.7 & 9.0 & 7.7 & 6.6 & 2.8 & 4.1 & 7.7 & 6.4 & 6.0 & 5.1 \\ \text { Feb-2008 } & 6.7 & 7.2 & 6.9 & 3.2 & 7.6 & 4.6 & 7.7 & 9.2 & 7.6 & 6.6 & 2.8 & 4.0 & 7.7 & 6.3 & 5.9 & 5.1 \\ \text { Mar-2008 } & 6.7 & 7.2 & 6.7 & 3.1 & 7.5 & 4.9 & 7.7 & 9.4 & 7.6 & 6.6 & 2.8 & 3.8 & 7.6 & 6.3 & 5.9 & 5.2 \\ \text { Apr-2008 } & 6.7 & 7.3 & 6.6 & 3.1 & 7.4 & 5.0 & 7.5 & 9.9 & 7.6 & 6.8 & 2.8 & 3.7 & 7.6 & 6.2 & 5.8 & 5.1 \\ \text { May-2008 } & 6.8 & 7.4 & 6.6 & 3.1 & 7.4 & 5.3 & 7.5 & 10.5 & 7.7 & 6.8 & 2.8 & 3.6 & 7.6 & 6.3 & 5.6 & 5.3 \\ \text { Jun-2008 } & 6.9 & 7.5 & 6.9 & 3.1 & 7.3 & 5.6 & 7.5 & 11.0 & 7.7 & 6.8 & 2.7 & 3.6 & 7.7 & 6.3 & 5.6 & 5.4 \\ \text { Jul-2008 } & 7.0 & 7.5 & 7.3 & 3.2 & 7.2 & 6.0 & 7.6 & 11.4 & 7.8 & 6.8 & 2.7 & 3.7 & 7.8 & 6.4 & 5.8 & 5.7 \\ \text { Aug-2008 } & 7.0 & 7.6 & 7.4 & 3.3 & 7.2 & 6.3 & 7.6 & 11.8 & 7.9 & 6.8 & 2.7 & 3.7 & 7.8 & 6.4 & 6.0 & 5.8 \\ \text { Sep-2008 } & 7.1 & 7.7 & 7.3 & 3.4 & 7.1 & 6.6 & 7.6 & 12.5 & 8.0 & 6.8 & 2.7 & 3.8 & 7.8 & 6.5 & 6.3 & 6.0 \\ \text { Oct-2008 } & 7.3 & 7.9 & 7.1 & 3.6 & 7.1 & 7.1 & 7.9 & 13.2 & 8.1 & 7.0 & 2.7 & 4.0 & 7.9 & 6.6 & 6.7 & 6.2 \\ \text { Nov-2008 } & 7.4 & 8.0 & 7.0 & 3.8 & 7.1 & 7.7 & 7.9 & 14.0 & 8.3 & 7.0 & 2.7 & 4.1 & 7.9 & 6.7 & 7.0 & 6.3 \\ \text { Dec-2008 } & 7.6 & 8.2 & 7.1 & 4.1 & 7.1 & 8.2 & 7.9 & 14.7 & 8.4 & 7.0 & 2.8 & 4.2 & 8.2 & 6.8 & 7.0 & 6.5 \\ \text { Jan-2009 } & 8.0 & 8.5 & 7.5 & 4.4 & 7.2 & 9.3 & 8.7 & 15.6 & 8.6 & 7.4 & 2.8 & 4.2 & 8.5 & 7.1 & 7.3 & 6.8 \\ \text { Feb-2009 } & 8.2 & 8.8 & 7.7 & 4.7 & 7.3 & 10.3 & 8.7 & 16.5 & 8.8 & 7.4 & 2.9 & 4.3 & 8.8 & 7.4 & 7.6 & 7.1 \\ \text { Mar-2009 } & 8.5 & 9.0 & 8.0 & 5.2 & 7.5 & 11.0 & 8.7 & 17.2 & 9.0 & 7.4 & 3.1 & 4.4 & 9.1 & 7.7 & 8.0 & 7.2 \\ \text { Apr-2009 } & 8.7 & 9.2 & 8.1 & 5.7 & 7.6 & 11.5 & . . & 17.6 & 9.1 & . . & 3.2 & 4.3 & 9.2 & 8.0 & 8.4 & 7.5 \\ \text { May-2009 } & 8.8 & 9.3 & 8.1 & 5.9 & 7.7 & 12.0 & . . & 17.9 & 9.3 & . . & 3.2 & 4.4 & 9.3 & 8.3 & 8.8 & 7.6 \\ \text { Jun-2009 } & 8.9 & 9.4 & 8.1 & 6.2 & 7.7 & 12.2 & . . & 18.1 & 9.4 & . . & 3.3 & 4.4 & 9.3 & 8.5 & 9.0 & 7.8 \\ \text { Jul-2009 } & 9.0 & 9.5 & 8.0 & 5.9 & 7.7 & 12.5 & & 18.5 & 9.8 & & 3.4 & 4.4 & 9.2 & 8.7 & 9.2 & \end{array}$




$\begin{array}{llllllllllllll} & (17) & (18) & (19) & (20) & (21) & (22) & (23) & (24) & (25) & (26) & (27) & (28) \\ \text { Jan-2008 } & 6.2 & 4.6 & 4.8 & 10.4 & 3.8 & 6.0 & 4.5 & 4.3 & 7.8 & 6.0 & 7.9 & 5.7 \\ \text { Feb-2008 } & 6.2 & 4.5 & 4.7 & 10.2 & 3.7 & 6.2 & 4.6 & 4.4 & 7.6 & 5.9 & 7.6 & 5.7 \\ \text { Mar-2008 } & 6.0 & 4.4 & 4.5 & 10.0 & 3.7 & 6.2 & 4.5 & 4.4 & 7.5 & 5.8 & 7.3 & 5.7 \\ \text { Apr-2008 } & 5.9 & 4.3 & 4.4 & 9.9 & 3.6 & 6.1 & 4.5 & 4.7 & 7.6 & 5.9 & 7.3 & 5.7 \\ \text { May-2008 } & 5.8 & 4.3 & 4.4 & 9.8 & 3.5 & 6.2 & 4.7 & 4.8 & 7.7 & 6.0 & 7.2 & 5.7 \\ \text { Jun-2008 } & 5.6 & 4.3 & 4.4 & 9.5 & 3.5 & 6.4 & 5.2 & 4.9 & 7.8 & 6.0 & 7.1 & 5.7 \\ \text { Jul-2008 } & 5.5 & 4.3 & 4.4 & 9.2 & 3.6 & 6.9 & 5.8 & 4.9 & 7.8 & 5.9 & 7.0 & 5.8 \\ \text { Aug-2008 } & 5.3 & 4.3 & 4.3 & 9.0 & 3.5 & 7.4 & 6.4 & 5.0 & 7.9 & 5.9 & 6.9 & 5.8 \\ \text { Sep-2008 } & 5.2 & 4.3 & 4.1 & 9.0 & 3.6 & 8.1 & 6.6 & 5.1 & 7.9 & 5.8 & 6.8 & 5.8 \\ \text { Oct-2008 } & 5.1 & 4.4 & 4.3 & 9.0 & 3.7 & 9.1 & 7.2 & 5.0 & 7.8 & 6.0 & 6.8 & 5.9 \\ \text { Nov-2008 } & 5.1 & 4.5 & 4.2 & 9.2 & 3.8 & 10.3 & 8.1 & 5.2 & 8.1 & 6.2 & 6.9 & 5.9 \\ \text { Dec-2008 } & 5.4 & 4.7 & 4.3 & 9.4 & 4.1 & 11.4 & 9.1 & 5.4 & 8.4 & 6.1 & 7.1 & 5.9 \\ \text { Jan-2009 } & 5.6 & 5.1 & 4.6 & 9.7 & 4.2 & 12.4 & 10.1 & 5.6 & 8.8 & 6.4 & 7.4 & 6.2 \\ \text { Feb-2009 } & 6.0 & 5.5 & 4.9 & 10.1 & 4.4 & 13.2 & 11.2 & 5.8 & 9.3 & 6.6 & 7.8 & 6.2 \\ \text { Mar-2009 } & 6.4 & 5.8 & 5.3 & 10.6 & 4.8 & 14.2 & 12.1 & 6.0 & 9.7 & 6.8 & 8.0 & 6.2 \\ \text { Apr-2009 } & 6.5 & 6.0 & 5.7 & 11.0 & 5.1 & 15.4 & 13.0 & 6.1 & 10.0 & 7.0 & 8.1 & : \\ \text { May-2009 } & 6.6 & 6.1 & 6.0 & 11.3 & 5.3 & 16.4 & 14.3 & 6.3 & 10.2 & 7.1 & 8.2 & : \\ \text { Jun-2009 } & 6.8 & 6.3 & 6.1 & 11.7 & 5.4 & 17.1 & 15.6 & 6.4 & 10.3 & 7.2 & 8.2 & : \\ \text { Jul-09 } & 7.0 & 6.4 & 6.0 & 12.0 & 5.5 & 17.4 & 16.7 & 6.4 & 10.3 & 7.3 & 8.2 & :\end{array}$




$\begin{array}{llllllllllll} & (29) & (30) & (31) & (32) & (33) & (34) & (35) & (36) & (37) & (38) & (39) \\ \text { Jan-2008 } & 4.2 & 3.8 & 3.0 & 4.9 & 5.8 & 3.8 & 2.4 & 9.0 & 5.4 & 6.8 & 5.6 \\ \text { Feb-2008 } & 3.9 & 3.9 & 3.1 & 4.8 & 5.9 & 3.7 & 2.4 & 9.0 & 5.4 & 6.8 & 5.6 \\ \text { Mar-2008 } & 4.0 & 3.8 & 3.1 & 5.1 & 6.1 & 3.7 & 2.3 & 9.0 & 5.5 & 6.8 & 5.7 \\ \text { Apr-2008 } & 4.2 & 4.0 & 3.2 & 5.0 & 6.0 & 3.7 & 2.4 & 9.0 & 5.5 & 6.8 & 5.7 \\ \text { May-2008 } & 4.2 & 4.0 & 3.2 & 5.5 & 6.1 & 3.7 & 2.5 & 9.0 & 5.7 & 6.9 & 5.9 \\ \text { Jun-2008 } & 4.2 & 4.1 & 3.2 & 5.6 & 6.2 & 3.8 & 2.5 & 9.0 & 5.8 & 6.9 & 5.9 \\ \text { Jul-2008 } & 4.3 & 4.0 & 3.2 & 5.8 & 6.1 & 3.8 & 2.4 & 9.9 & 5.9 & 7.1 & 6.0 \\ \text { Aug-2008 } & 4.1 & 4.1 & 3.2 & 6.2 & 6.2 & 3.9 & 2.4 & 9.9 & 6.1 & 7.1 & 6.2 \\ \text { Sep-2008 } & 4.3 & 4.0 & 3.2 & 6.2 & 6.2 & 4.0 & 2.5 & 9.9 & 6.1 & 7.2 & 6.2 \\ \text { Oct-2008 } & 4.4 & 3.8 & 3.1 & 6.6 & 6.3 & 4.0 & 2.7 & 11.2 & 6.2 & 7.5 & 6.4 \\ \text { Nov-2008 } & 4.5 & 4.0 & 3.2 & 6.8 & 6.4 & 4.8 & 2.8 & 11.2 & 6.4 & 7.6 & 6.6 \\ \text { Dec-2008 } & 4.6 & 4.3 & 3.3 & 7.2 & 6.6 & 4.8 & 2.9 & 11.2 & 6.7 & 7.7 & 6.8 \\ \text { Jan-2009 } & 4.9 & 4.1 & 3.3 & 7.6 & 7.2 & 4.7 & 3.0 & 12.5 & 6.9 & 8.2 & 7.2 \\ \text { Feb-2009 } & 5.3 & 4.4 & 3.5 & 8.1 & 7.7 & 5.0 & 3.1 & 12.5 & 7.2 & 8.4 & 7.5 \\ \text { Mar-2009 } & 5.7 & 4.8 & 3.7 & 8.5 & 8.0 & 4.6 & 3.2 & 12.5 & 7.6 & 8.7 & 7.8 \\ \text { Apr-2009 } & 5.5 & 5.0 & 3.7 & 8.9 & 8.0 & 5.4 & 3.1 & . . & 7.8 & 8.8 & 8.0 \\ \text { May-2009 } & 5.7 & 5.2 & 3.9 & 9.4 & 8.4 & 6.1 & . . & . . & 8.1 & 8.9 & 8.3 \\ \text { Jun-2009 } & 5.8 & 5.4 & 4.0 & 9.5 & 8.6 & 5.6 & . . & . . & 8.2 & 8.9 & 8.3 \\ \text { Jul-2009 } & 5.8 & . . & . . & 9.4 & 8.6 & . . & . . & . . & . . & . . & . .\end{array}$

Notes. Countries are as follows

1 European
2. Euro area
3. Belgium
4. Denmark
5. Germany
6. Ireland
7. Greece
8. Spain
9. France
10. Italy

11. Netherlands
12. Austria
13. Portugal
14. Finland
15. Sweden
16. United Kingdom
17. Bulgaria
18. Czech Republic
19. SIovenia
20. Slovak Republic

21. Cyprus
22. Latvia
23. Lithuania
24. Luxembourg
25. Hungary
26. Malta
27. Poland
28. Romania
29. Australia
30. Japan

31. Korea 32. USA

33. Canada

34. Mexico

35. Norway

36. Turkey

37. G7

38. OECD Europe

39. OECD 
Figure 1. The Baltic Dry Index, 2005-2009

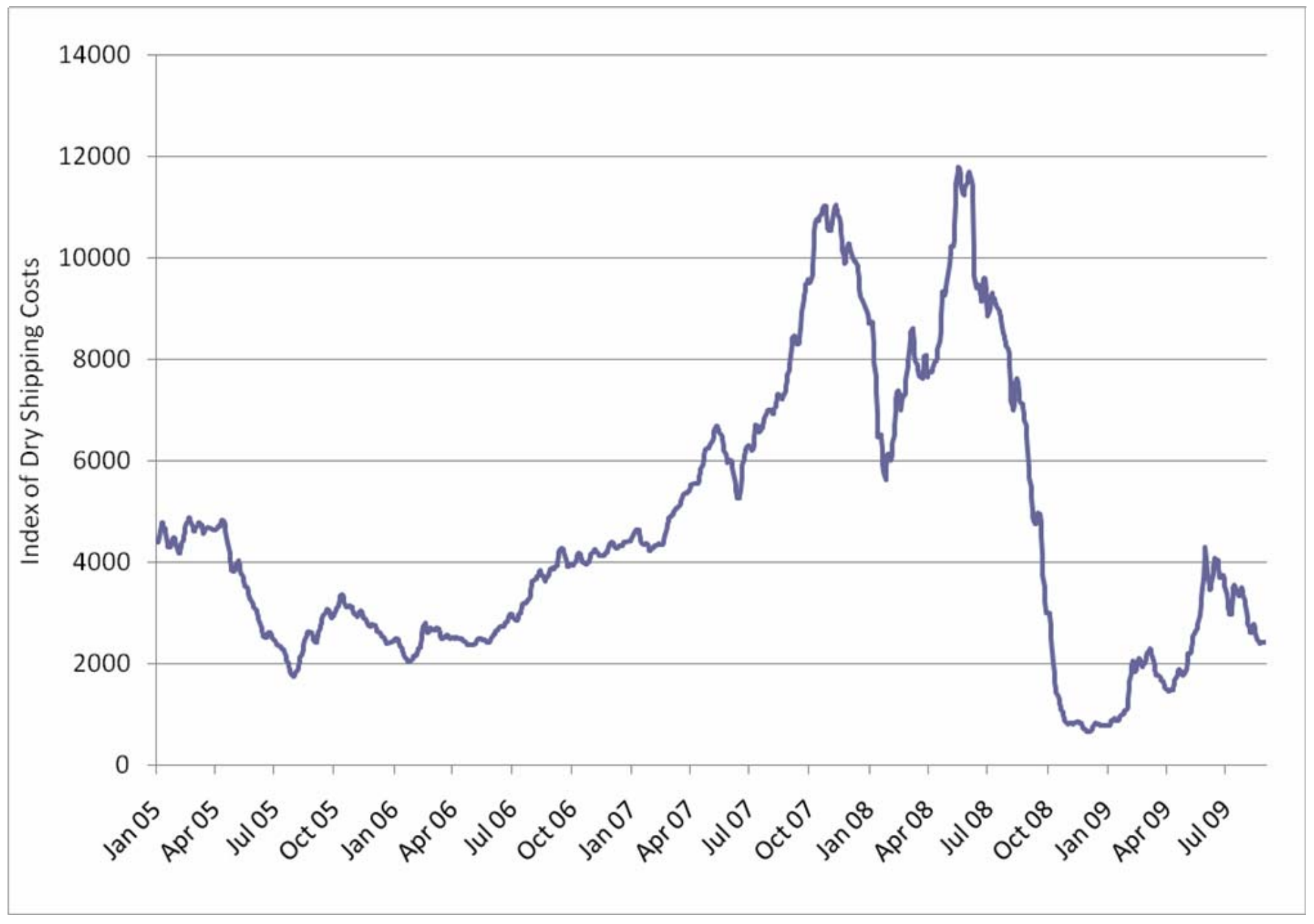


Figure 2: Deviation of G7 Output from Trend

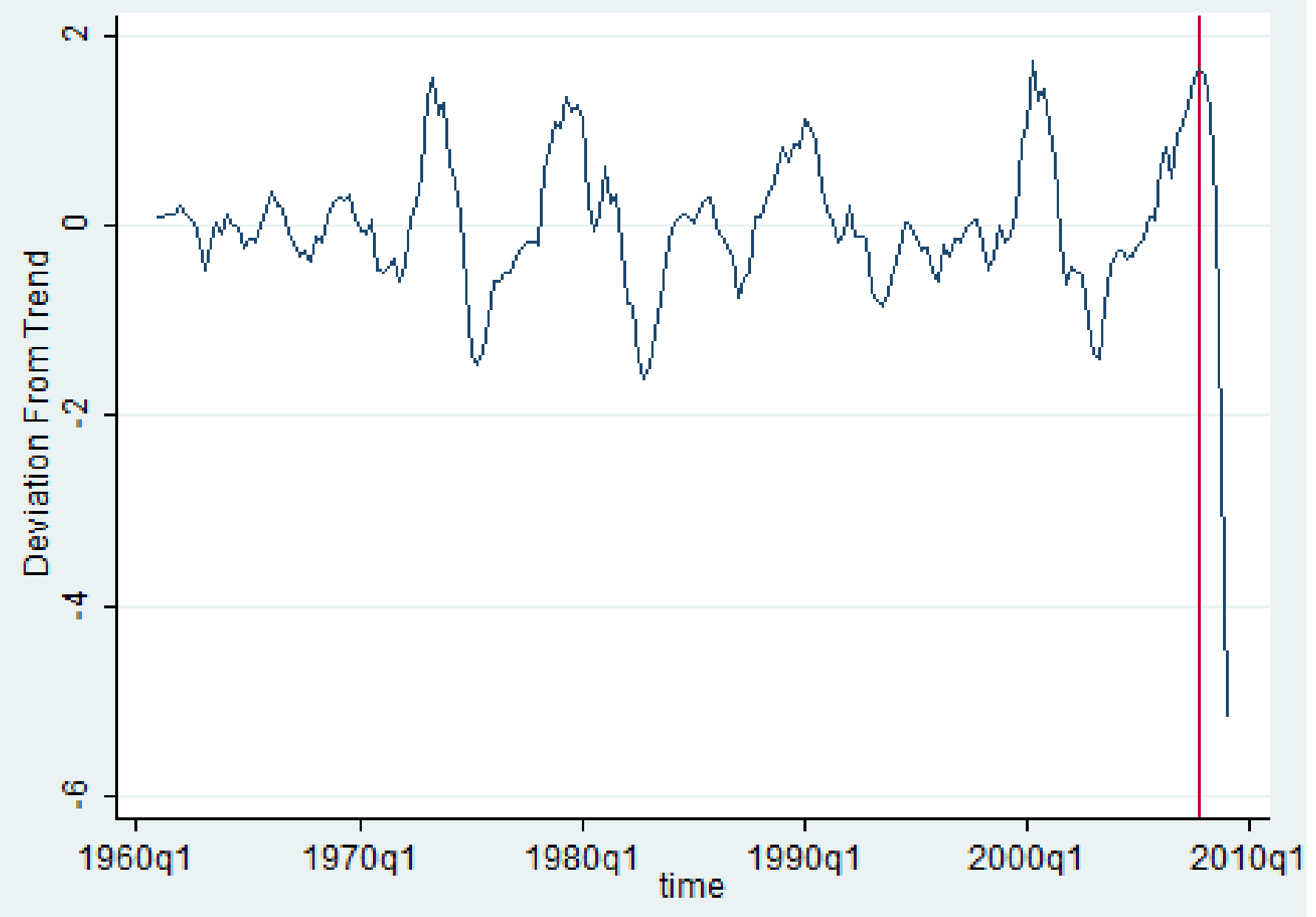

Source: OECD Main Economic Indicators 
Figure 3: Timing the Recession - USA
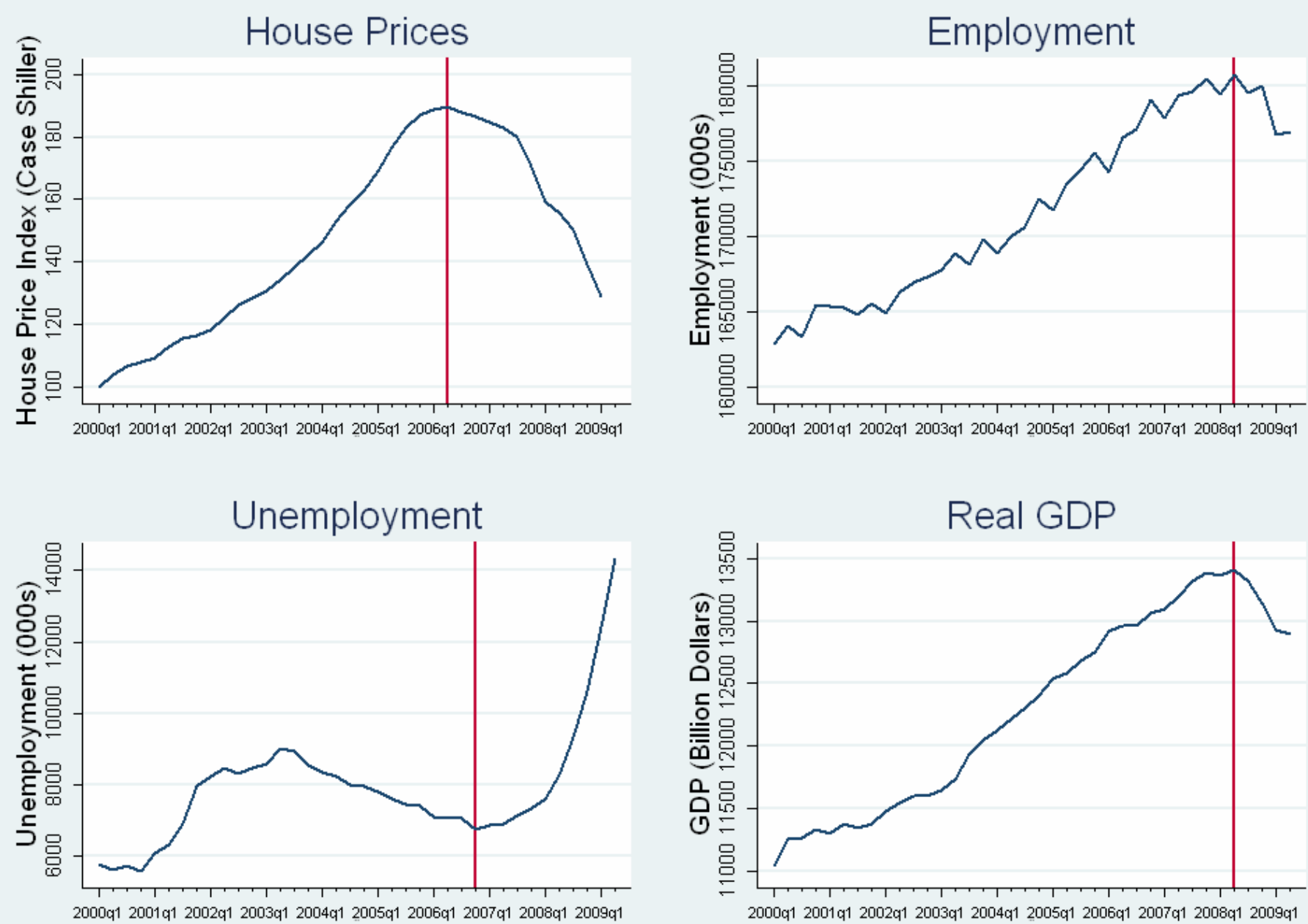

Source: OECD Main Economic Indicators and Standard \& Poors 
Figure 4: Timing the Recession - Germany
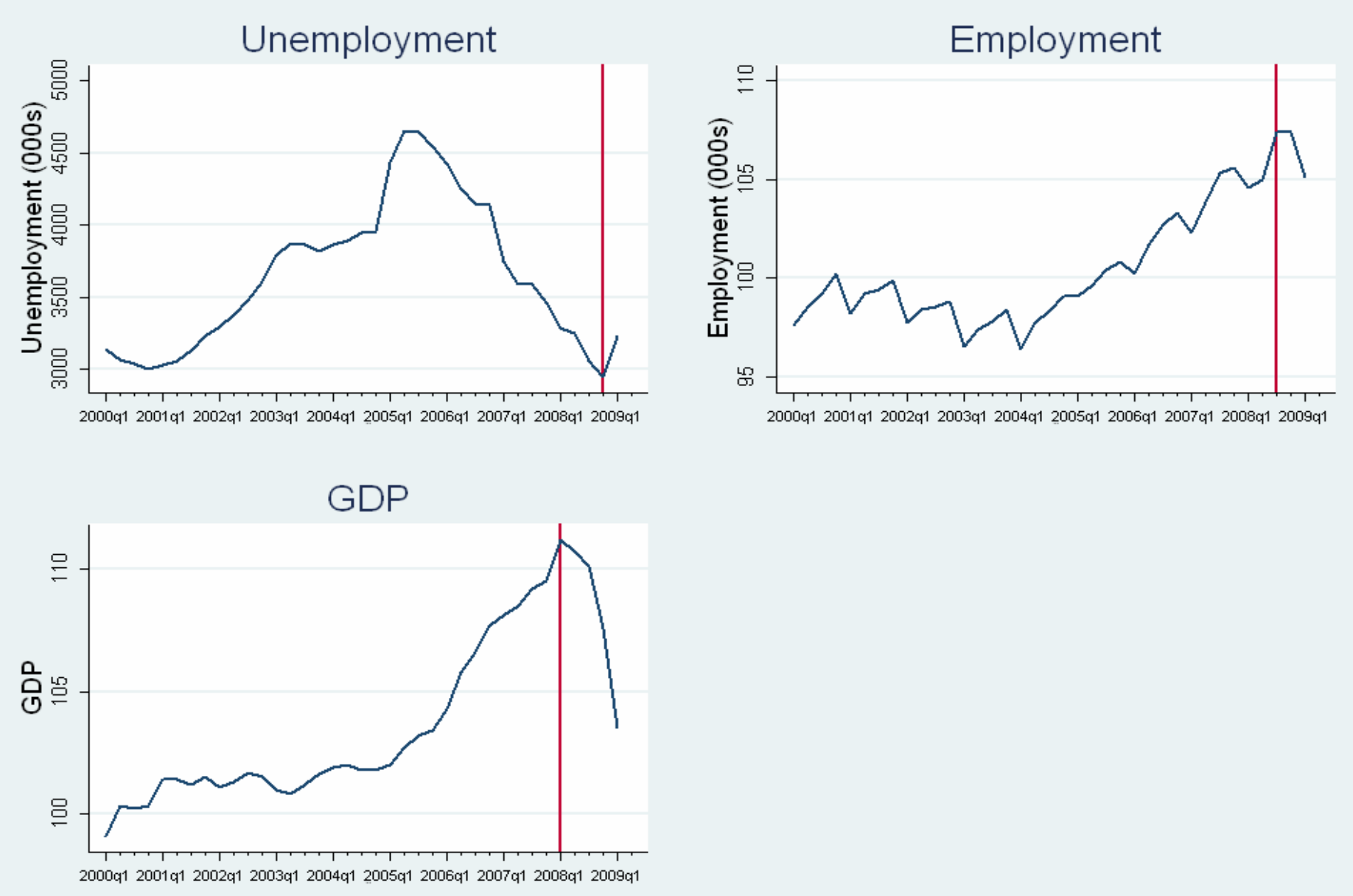

Source: OECD Main Economic Indicators 
Figure 5. Timing the recession - France
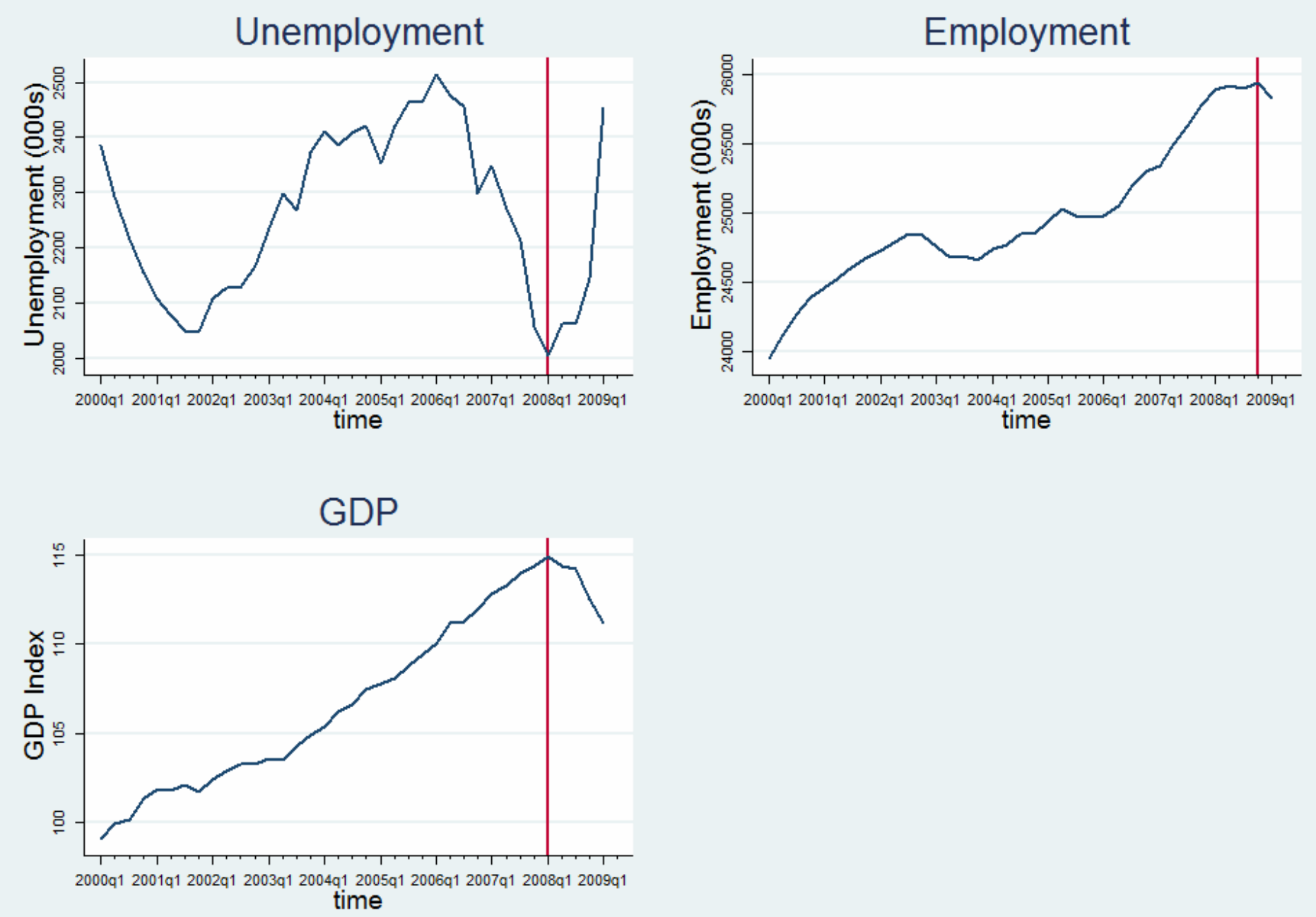
Figure 6. Timing the recession - UK
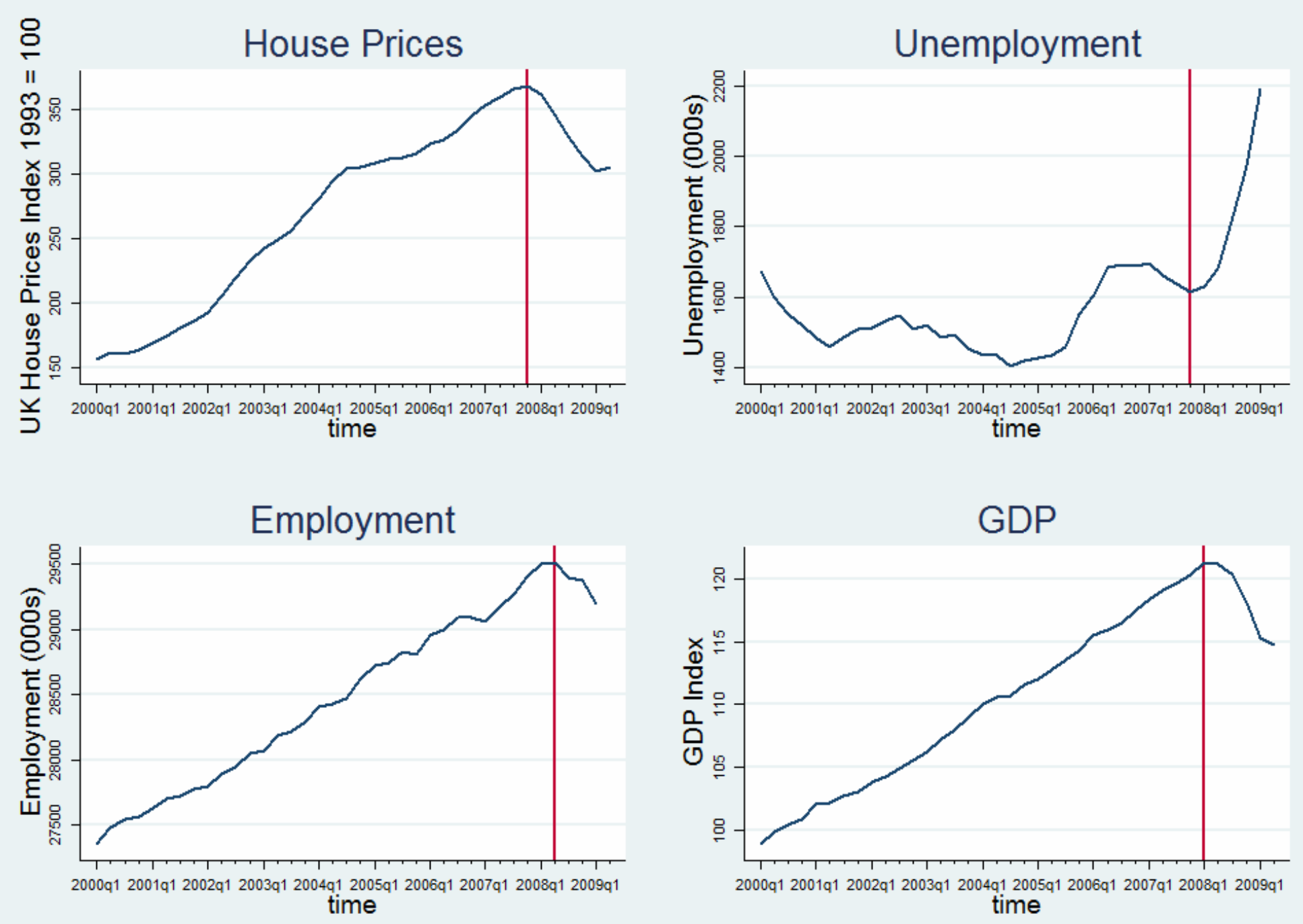
Figure 7. How do you expect unemployment to increase over the next 12 months? - EU

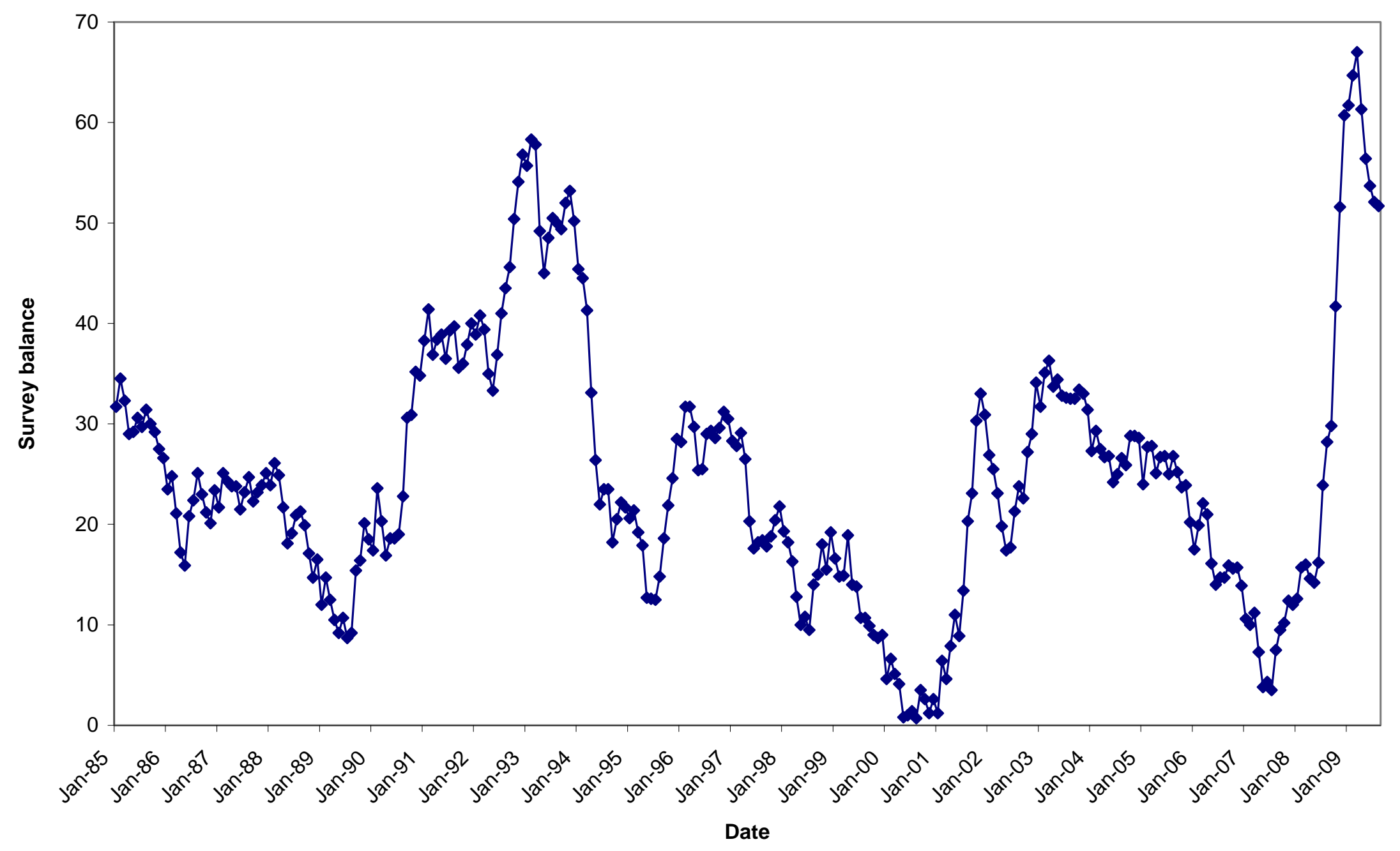

